\title{
Babylonian Populations, Servility, and Cuneiform Records
}

\author{
Jonathan S. Tenney \\ Cornell University \\ tenney@cornell.edu
}

\begin{abstract}
To date, servility and servile systems in Babylonia have been explored with the traditional lexical approach of Assyriology. If one examines servility as an aggregate phenomenon, these subjects can be investigated on a much larger scale with quantitative approaches. Using servile populations as a point of departure, this paper applies both quantitative and qualitative methods to explore Babylonian population dynamics in general; especially morbidity, mortality, and ages at which Babylonians experienced important life events. As such, it can be added to the handful of publications that have sought basic demographic data in the cuneiform record, and therefore has value to those scholars who are also interested in migration and settlement. It suggests that the origins of servile systems in Babylonia can be explained with the Nieboer-Domar hypothesis, which proposes that large-scale systems of bondage will arise in regions with
\end{abstract}

* This was written in honor, thanks, and recognition of McGuire Gibson's efforts to impart a sense of the influence of aggregate population behavior on Mesopotamian development, notably in his 1973 article "Population Shift and the Rise of Mesopotamian Civilization". As an Assyriology student who was searching texts for answers to similar questions, I have occasionally found myself in uncharted waters. Mac's encouragement helped me get past my discomfort, find the data, and put words on the page. The necessity of assembling Mesopotamian "demographic" measures was something made clear to me by the M.A.s.s. project, and I extend my thanks to the late Tony Wilkinson for allowing me to participate in that effort. This paper has benefitted immeasurably from the assistance of Lynn Johnson of the Cornell University Statistical Consulting Unit and the scrutiny of anonymous reviewers. A much-reduced version of this paper was first presented at the "Life at the Margins: Questions in Ancient Near Eastern Social History" workshop, co-organized by J. Nicholas Reid and Jonathan Valk. The workshop was funded by New York University's Institute for the Study of the Ancient World. 
plentiful land but few workers. Once established, these systems persisted and were reinforced through Babylonia's high balance mortality, political ideologies, economic incentives, and social structures.

\section{Keywords}

slavery - Babylonia - Mesopotamia - demography - politics - settlement - taxation population - Wet nursing - marriage - household

... population evidence has not generally be sought after, although it must play a major role in any study of man.

ROBERT BRAIDWOOD AND CHARLES REED (1957)

\section{Introduction}

Systems of coerced labor are visible in visual representations and written records at the onset of political complexity in Mesopotamia and remain conspicuous throughout its long history. They are closely tied to the development of religious, political, and aristocratic institutions. A variety of labels have been ascribed to these systems and their members, including corvée, slavery, serfdom, dependency, forced labor, prisoners, captives, deportees, wards of the state, and oblates. While some of this lexical variety can be attributed to the difficulties endemic in the translation of cuneiform texts, it is also an artifact of the way ancient peoples chose to label themselves and how Assyriologists and archaeologists reconstruct institutional systems. An underlying assumption of scholarly treatments is that servile people were legally, socially, and experientially distinct from the rest of the population. Recent work by scholars of comparative slavery suggest that we must reconsider this presumption, because it is now possible that most labor in the West prior to the nineteenth century and perhaps in all pre-modern complex societies was not freely given (Eltis and Engermann 2011: 3). They have emphasized that servility is as much defined by the lived experience of the subject as by legal category, and proposed that the buying and selling of people is not the only way to distinguish slavery from freedom. 
Prosaic descriptions of how Mesopotamian servile systems operate are scarce in native sources, but explanations of their place in the political consciousness of centralizing polities are unmistakable. These justifications are generated by the entities that benefit from the system's existence. As a consequence, the narratives are slim, celebratory, and do not bemoan the plight of the oppressed. Likewise, art and iconography from multiple phases of Mesopotamian history depict captives and laborers with unapologetic pride. The enslaved can appear naked and bound by their arms, lashed by their necks into human chains, or hooked through the nose. Deported families trek across the wilderness, and gangs of workers carry earth or pull loads under the watchful eyes of overseers and soldiers bearing prods and weapons. (Ataç 2010: 46, 69; Barnett 1960: 21, 45, 158; Börker-Klähn 1982: 4 18d, 20, 21b, 31; Moortgat 1967: 134-38; Reade 1998: 26, 53, 66, 70, 86-87). When found in situ, it is clear that these images were placed in locations where they would have the greatest effect as expressions of conquest, domination, and control. ${ }^{1}$

Using ancient evidence and modern interpretation, Assyriologists have studied the lexicon of servility and assigned the servile people of Mesopotamia into categories. Some of the factors leading to these divisions are legal status (Westbrook 2003: 40), duration and/or conditions of labor obligation (Evans 1963; Postgate 2007), and mechanism of servile inducement, such as capture (Seri 2013), forced migration (Oded 1979; Postgate 2013:17-8), birth (Dandamaev 1984), residence (Gelb 1972, Steinkeller 2015b; Stol 1995b), or votive dedication (Kleber 2011). A survey of this literature also reveals that servility is inextricable from six other important topics studied by Assyriologists:
1. Labor
2. Women
3. Foreigners
4. Taxation
5. Land Use
6. Settlement

The reasons can be briefly summarized. First, many Assyriological studies of labor and labor power are based on institutional records of servile systems.

1 Some of these issues are present in very early Mesopotamian texts (Foster 2010). For another interpretation of similar evidence from the early centuries of Babylonia, see Steinkeller 2015b: 150-53. The volume in which it appeared was released after this article was written (Steinkeller and Hudson 2015). Anyone who reads that volume and this article will find that I share the opinions of several of its contributors, Steinkeller and Richardson in particular. When possible, credit was given to them in the final stages of the editing process. 

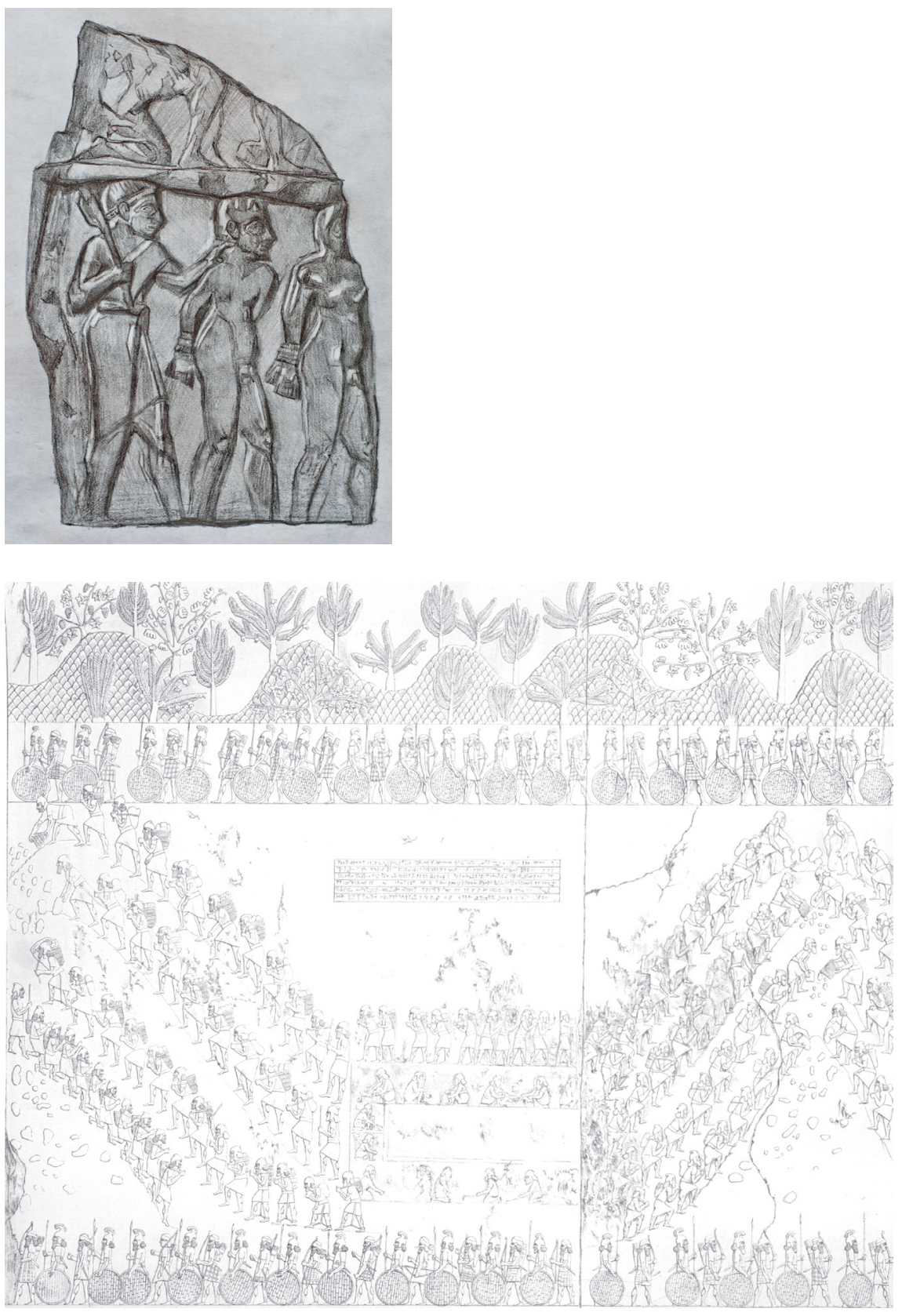

FIGURES 1 A-B

Mesopotamian depictions of captives and servile laborers (1a: artist rendering of stele from Susa by R. Constantine; 1b: Layard 1853: plate 14).

Inscription of $b$ : "I had the soldiers of enemy settlements and insubmissive troops of the mountains whom I had captured wield iron axes and picks [and] they quarried large bull colossi for the gates of my palace" (Grayson and Novotny 2014: 118). 
Second, women and foreigners often appear in these same administrative documents (Stol 1995a: 137). Moreover, women were particularly susceptible to servile induction in Babylonia. Third, some forms of forced labor, such as corvée, could be considered a tax, in this case a tax in labor. At least some land was taxed in kind by governments and/or institutions; and areas under cultivation could be expanded to increase production and the tax base (Wilkinson et al. 2005: 25). Governments also acquired and distributed land (Van de Mieroop 2004: 55). Fourth, servile workers were used in agricultural production and in the maintenance of irrigation infrastructure. Fifth, settlement is related to the development of recently acquired or underutilized agricultural land, and new settlement has been attributed to the forced relocation of people to farm this land and to work for the state (Dandamaev 1984: 3-4; Oded 1979; Brinkman 1963: 239).

This lexical approach is the basis of all Assyriological research. However, in the matter of servility it has its shortcomings. Scholars of comparative slavery have known for some time that categories of servility—slavery in particularare difficult to define and have muddy and porous borders (Eltis and Engerman 2011). The categories listed above illustrate this point. For example, a person performs corvée because he lives in a region or on an estate that is subject to a labor tax. Corvée is also temporary, and in some cases reflects a legal status or contract. Deportees are both captives and forced migrants, which means that certain distinct demographic features (skewed sex ratios, etc.) will manifest in both groups. Furthermore, comparativists have attempted and largely failed to develop an all-inclusive definition of slavery, especially as a status distinct from other types of forced labor. They have also abandoned a stark division between free and unfree peoples in favor of more nuanced considerations (ibid.: 7-10). Wage earning was once considered a characteristic marker of free laborers, but it is now established historical fact that people living in bondage can work for wages (Fogel and Engermann 1974: 56 ). It is also true that slavery can be present in places where it is illegal or when a person's status as slave is unrecognized or disavowed by the government. ${ }^{2}$

Babylonia's written record is vast and its social history is long and complex, which means that studies of servile people face additional hurdles. There are four principal issues: translation, identification, documentary continuity, and historical characterization. First, translations are problematic because one-toone correspondences between ancient words and modern translations can be

2 This continues to be a worldwide phenomenon. The plight of workers in the brickyards of Asia is one example (http://www.dailymail.co.uk/news/article-2858775/Paying-debts-brick -brick-Pakistani-modern-day-slaves-trapped-lifetime-hardship.htmlandhttp://www.nytimes .com/2011/03/16/world/asia/16kiln.html). 
elusive. The word for a male slave, $a r d u$, has a clear meaning in legal texts and law codes, but also appears in unexpected places. It can be found as an element in the names of royalty and elite families and also in important occupational titles for persons who do not appear to be owned (Brinkman 1980: 21-2, 1982: 7-8). ${ }^{3}$ Assyriological dictionaries have resolved this conundrum by expanding the meaning of the word to include a wide range of subordinate, nonsubordinate, and generally—but not necessarily—servile positions. ${ }^{4}$ Assyriologists have also interpreted the names as expressions of slavish religious devotion. To complicate matters further, the main Akkadian word denoting the granting of freedom to a servile person and its resulting status, zak $\hat{u}$, also describes the act of clearing a person and state of being clear of any legal claims, debts, or obligations. In isolated contexts, one cannot always determine if an indication that a person is "clear" refers to the satisfaction of a lawsuit, the manumission of a slave, the alleviation of taxes, or some other type of release.

Along similar lines, escapees are endemic in the records of laboring peoples. They are usually marked by verbs whose infinitives have the basic meaning of "to disappear", zÁH and halāqu. If a text indicated that a worker has "disappeared," does it mean that the person is a "free" person who failed to show up for work, or a fugitive slave on the run? For some periods, the answer seems clear because recaptured runaways are imprisoned; but this may not be universally true throughout Mesopotamian history (Tenney 2011a: 106; Reid 2015: 581-82). Questions also surround the word dullu, translated as "work assignment" in administrative entries, but as "corvée", "forced labor", or simply "toil" in literary and royal narratives (section 12).

The second issue concerns identification. It is accepted that a legal transaction describing a person giving a second human being to a third person in exchange for financial remuneration is a clear-cut slave sale. Because the same features are present in marriage contracts, it has been argued that brides were also sold, thus raising the question of the level of choice and agency afforded a Babylonian woman at critical points in her life (Koschaker 1950; Westbrook 2003: 46-8). Sales, contracts, and court documents are an obvious source of information on human bondage, but state records remain a vast and mostly untapped source for studying large-scale, institutional servility. For the most part these texts are limited to essential information, and are barely more than lists of names, occupations, assignments, and material allocations. When these

3 E.g., Warad-Sîn, Arad-Ea, or arad ekalli. The same circumstance extends to Sumerian names, e.g., árad (Di Vito 1993: 225).

4 E.g., "Servant of Sîn", "servant of the palace" in the first case, "Slave of Sîn", "Slave of Ea" in the second. For earlier periods, see Foster (2010: 148). 
documents are damaged, lack key administrative terms, or are viewed in isolation, it is nearly impossible to determine with certainty if the records pertain to wage laborers, institutional employees, corvée levies, slaves, forced laborers of a different type, or destitute people receiving food assistance. If workers of multiple origins are used for projects, they may be mixed together in texts (Foster 2010: 144-45). In this case, blanket declarations on the status of workers always carry a measure of uncertainty. ${ }^{5}$

Scholars of Mesopotamia use the word "corvée" to describe any mandatory, temporary work for the government. They may also generally accept the royal viewpoint that it was inconvenient, necessary, and benign. However, the few available instances in which ancient people expressed their own opinions suggest otherwise. Those who were obligated to service would plead for release, and there is evidence that they employed others to serve in their stead (Brinkman 1984a: 22-3; Stol 1995a: 298-300, 1995b: 295; Jursa 2015: 351; Steinkeller 2015b: 173; Postgate 2007: 113-4). Likewise, a Sumerian literary text, Gilgamesh and Aka, tells the story of the rise and fall of a rebellion by young men against the labor obligations imposed by the state. Corvée might not even be the most precise term to describe this type of forced labor. Perhaps it should be abandoned in favor of "statute labor", which refers specifically to labor legally imposed by political institutions, primarily for the construction of public works. Furthermore, people can be unfree even if the duration of their labor service was limited to only a part of the year (compare Steinkeller 2004: 94; Dahl 2010: 290; Stol 1995b: 293). Instances of definition and identification can also intersect. Is a person free if he can be incarcerated for not paying a labor tax, or failing to report for a private, wage-based job? The latter seems to have been the case in Babylonia. One of the primary characteristics of freedom is supposedly an individual's right to work when and where he/she chooses. Even in the United States, infamous for its incarceration rates of the poor, no one can be jailed for owing past-due taxes, only for cheating on their taxes or committing tax fraud.

The third issue covers questions of continuity and interpretation. The cuneiform record allows for lexical comparisons across long spans of time, and

5 For example, some supposed markers of people identified as corvée workers in administrative records from earlier periods are present in select records of the test population: possible substitute workers and organization/obligation by household units. However, it would be inaccurate to declare that these records are the products of a corvée system because these features are not common, some workers were definitely not corvée levies, and there are other equally valid explanations for these markers. From a bureaucratic standpoint, the people "look" the same on the texts regardless of origin. 
it can be tempting to use insights into social categories from one set of documents to clear up ambiguities in an archive from another historical period. However, analogies of this sort are unsecure if neither group is properly understood. This problem can be acute when the research concerns periods of great social and demographic change. The mid-second to early first millennium is one such instance, and there are several indications that words differentiating social categories in the past were modified to fit a new social reality. For example, in legal contexts awilum/amilu over the course of several centuries transitions from the label of a full citizen to a term that qualifies slaves being sold and is used in the abstract to denote such subservient status (Brinkman 1980: 20-1). ${ }^{6}$ This same word (or its Sumerian equivalent) in other periods has been said to indicate a human being in general, so Assyriologists have assigned it both generalized and specific meanings depending on context and textual genre. ${ }^{7}$ When contextual clues are missing, the choice of translation can be arbitrary and has a profound impact on the tone and interpretation of the text. It is also true that some of the markers of working or servile groups are attested over the longue durée, but their meanings are not continuous by default. Scholars may not even agree that they are terms of servile status, even if they can be used to identify servile people (compare Dahl 2010: 291; Sallaberger and Pruß 2015: 70; Tenney in press). The administrative designation GURUŠ is a case in point. It is common in early administrative documents and reappears as a bureaucratic term after the residential and social upheaval of the mid-second millennium. This later usage could be attributed to administrative and social continuity or seen as a bureaucratic revival inspired by the respect Babylonian scribes paid to the archaic traditions of Nippur and Sumer (Tenney 2016). ${ }^{8}$ The evidence that might support either claim is inconclusive, primarily because one cannot quantify or measure the degree to which the hyper-conservative cuneiform medium colors our view of the past. Simply put, reconstructions of a society provided by coarse impressions from texts can never be compared with past social realities.

6 Another example might be the different contexts and development of énsi/iššakku, a city ruler in the third millennium but an obviously subordinate, although as yet undefined, type of farmer in the later second millennium. The CAD's claim that iššakkus retained some degree of privilege in later periods should be reconsidered, since they are enmeshed in government service and/or receive food disbursals from the state in the Nippur area (CAD 7: 262-66).

7 E.g., We can see how context makes a difference, even if a subtle one, with the Sumerian word lú as well. It has been given a definitions that are general ("person, mann," used for males and females) and specific (male or female heads of household) (Gelb 1979: 51; Jacobsen 1987: 130).

8 Whether the term is ever used as an abstract means of measuring labor in the Kassite period (the man-day) has yet to be determined (Steinkeller 2015a: 1). 
The fourth element that has influenced the discourse on servility is a historical characterization based on an early hypothesis that has been revived and adapted to accommodate a new, expanded interpretation of household. Some Assyriologists have characterized early governments of northern Babylonian peoples as warlike and exploitative, and southern governments as socially conscious and constructed around institutional households and inclusive economic structures (Steinkeller 1993: 120-1). These two regions were in conflict in the late third millennium and it is claimed that the southern institutional system eventually disappeared. ${ }^{9}$ The debate over whether institutional workers were free or nonfree has been conducted primarily by scholars who study the records from this time, and the third millennium has become something of a chronological fulcrum for those who debate the relationships between Babylonian governments, elites, and their workers. Scholars who study later periods seem more willing to accept widespread institutional servility. The late third and early second millennium may have indeed been a watershed political moment, but much of the free vs. nonfree debate may have been facilitated by the third millennium corpus concerning institutional workers because it is both very extensive and largely laconic. Likewise one cannot discount the effect that Neo-Assyrian royal inscriptions, annals, and palace reliefs may have on scholars of later times because they recount deportations of tens of thousands of people and graphically depict brutal treatment of outsiders. ${ }^{10}$

Despite the terse and ambiguous nature of much of the evidence, Mesopotamian scholars continue to trace the divide between unfree and free or slave and citizen, examine the terms and labels used to identify people, and relate them to the institutions composing the written record. The scope and character of large-scale institutional servitude and freedom are still often reduced to an exchange of opinions by two men, I.J. Gelb and I.M. Diakonoff, that took place over 40 years ago (Diakonoff 1972; Gelb 1972). The discussion had old roots (Struve 1969a-b, published first in Russian in 1933 and 1948) and is today more historical anachronism than a useful means of bracketing the complex and enduring forms of servility in Mesopotamia. The construal of a singular social "class" is a distortion based on a reductionist cuneiform record, and elucidating the nested identities of Babylonians would most likely be a more profitable pursuit. Recent publications have added to existing social

Like many shifts in Mesopotamian government, it can be difficult to pin down the mechanisms and even the timeline of such changes. Van de Mieroop has posited that one of the more important indicators - a shift from temple to state control of some land-happened during the reign of Rīm-Sîn of Larsa (1993: 61-62; cf. Charpin et al. 2004: 127).

Rulers from earlier periods made similar claims in their inscriptions, but scholars have questioned the validity of their royal boasts, thus reinforcing the intellectual status quo. 
frameworks, pointed out the difficulties with some records, and have also admirably tried to quantify labor output and labor in general. Important research has brought forward new information on wage labor and demonstrated that at least in the sixth century, administrators were forced to use more wage laborers than the cheaper servile workers on some projects (Steinkeller and Hudson 2015; Jursa 2014 and 2015).

In sum, each scholar must weigh the entirety of the evidence, then either judge if the systems and persons being studied are servile, equivocate, or ignore the question altogether. The intellectual process is difficult because we are unable to securely identify the motivations of institutions and rulers, which were most likely oriented towards securing their own positions and interests. Any benefit to the workers claimed or observed in the actions of elites may be false or accidental. I myself have struggled with all of the issues already mentioned, especially with questions of interpreting words in isolated contexts. I found that all four of the preceding issues can be reduced to a series of overarching questions that are largely unanswerable without intellectually uncomfortable assumptions. Should we assume that large-scale institutional servile systems are cruel and ruthless, or can they be a means to provide for the unfortunate and harness underutilized labor power (Postgate 1994a: 136)?11 Is it possible to evaluate the population starkly in terms of free and unfree? Even the most neutral classification that has been devised to avoid the question of slavery and coercion, "dependent," is itself not above criticism because all human beings are dependent on something else and no one is entirely free from social rules, biological needs, and the laws of the physical world. ${ }^{2}$ How

11 Recent hypotheses on the prison-industrial complex in the United States have posited that it functions as a system that turns an unexploitable underclass into highly exploitable cheap labor (Smith and Hattery 2007).

12 Here, "dependency" is employed in its original application to servile workers-a definition based on a dependency of basic survival—where destitute or legally powerless people are bought, stolen, or otherwise given over to institutions for the purpose of labor extraction. More recently, scholars of Mesopotamian legal texts have used it to describe free children, wives, and siblings with limited legal liability because they are the responsibility of a free, male household head. One could argue that they are both dependents in the same legal sense because the institution assumes the role of head of household and both are provided food and shelter. This is a fair assessment, but it ignores the very different circumstances and power dynamics by which individuals from each category become "dependents," not to mention the widely divergent futures faced by individuals from both groups. Therefore, my point applies to a single usage of "dependent," admitting that it can be difficult to determine which of the two usages are being employed by a scholar in a particular academic work. 
many references to the poor treatment of runaways are needed before one can conclude that a system was oppressive (Tenney 2011a; Reid 2015; Kleber 2012)? Do Mesopotamian administrative recording systems adapt to social change and accurately reflect the past, or are the social histories that depend on these sources crippled by archaisms and conservative writing? Can the bias of the record be identified, measured, and corrected? Lastly and most importantly, value judgements about the degrees of unfreedom inherent in servile categories are made in near complete ignorance of how the person or persons self-identified, which is probably the only true means of determining whether a person is free or unfree (cf. von Dassow 2011).

\section{$1 \quad$ Complementary Methodologies}

As a complement to lexical approaches, servility could be recognized as a collective phenomenon that is not restricted to legal categories and matters of salability. With a more expansive perspective, different research methodologies could be employed to gain a better understanding of the lived experience of all servile peoples. One could adapt the statistical methods familiar to quantitative historians, historical demographers, and nearly all other humanistic social sciences to the documentary record of Mesopotamia, which is rich with such data. Recently, quantification has been used to analyze pricing trends in the long sixth century and to calculate labor values (Jursa 2010, 2015; Richardson 2015), but its use in large collections of population data is just beginning (Galil 2007; Tenney 2011a). This alternative paradigm permits analysis of servile people separate from scribal practice, bureaucracy, labor, and taxation. Study subjects do not have to be shoehorned into a particular category of unfreedom to appease the most conservative of lexicalists. One also does not have to resort to anachronisms and outdated definitions of slavery, or make conclusions from less than ideal sample sizes (cf. Gelb 1972; Westbrook 2003: 38, 54-5; Patterson 1998: 38; Kleber 2011: 105). It becomes possible to determine whether there was a substantial difference among the core experiences of servile people of all categories and also with the general population, which were probably very similar in some areas (mortality, family structure). One can also add to the growing body of research on women and the social, demographic, and institutional environment in which they made major life choices. It may also emphasize women's roles as leaders of households and participants in industry.

The approach is limited to a particular set of questions and requires contextual framing that can only be provided with the types of philological and 
historical methods that have characterized studies of servility up to this point. However, if servile groups can be positively identified and it can be determined within reason that the statistics compiled from the record are not a result of scribal bias, it may be possible to develop more complex narratives for servile people and perhaps the majority of Babylonians. Because the results may lack context, it presents an opportunity for methodological inclusivity. For example, one could frame the choice and agency of servile workers in functionalist, systemist, or agent-based theoretical approaches (Ur 2014).

This paper is a test case using data mined from administrative tables and other records from second millennium BCE Babylonia, a kingdom in Iraq whose borders stretched roughly from the modern city of Samarra to the southern borders of the Dhi Qar governorate. It considers one servile population as it relates to the Babylonian population as a whole, especially the biological challenges to population growth. It discusses foundational social structures and familial institutions, specifically ages of weaning and first marriage, mortality, birth spacing, household size, and inheritance practices. All socially complex populations prior to the great demographic transition and the invention of modern medicine share similar average measures in most of these important demographic features, or at the very least they tend to fall within a narrow range of possibilities (Burch 1967: 349-50, 353; Levy 1965: 41-2, 49; Coale 1971: 1; Hajnal 1965: 101; Huebner 2013: 49; Hanley 1974: 141; cf. Ur 2014: 254-55). Comparisons with other early groups are therefore valid and beneficial because they can reveal root causes for what is observed in ancient statistics, especially when such explanations are lacking in the cuneiform record. At present, insight gleaned by comparing an unknown Mesopotamian population to at least one culturally and socially understood group from outside the region can lead to greater insight of demographic causation than a comparison of two Mesopotamian groups that have no grounding in the contemporary consciousness. ${ }^{13}$ Moreover, this cross-disciplinary approach is the best way to "put the scanty data available ... into perspective and provide a counterweight to the tendency to overemphasize a few known factors or facts"(Hin 2013: 174-5); which is a strong impulse in fields with deep roots in philology and etymology. The paper also discusses ages and life stages, which in turn permit an estimate of system-wide costs.

After meandering through several genres of documentation and methods of analysis, this exploration will reveal several possible reasons why servile systems are endemic in the Babylonian record even though the region had a tradi-

13 This does not mean, of course, that there is no insight to be gained from the latter. It can be very helpful in understanding recording systems. 
tion of paid labor. H.J. Nieboer and Evsey Domar have proposed that servility arises in regions with plentiful land but few workers (Eltis and Engermann 2011: 13). They have argued that throughout history, there cannot be a circumstance where free land, free agricultural workers, and non-working landowners exist at the same time. When low population, undeveloped or underdeveloped land, wages, landowning elites, and governments whose interests lead them to support these elites are all concurrently present, the political establishment will create one or more systems of servility to restrict the mobility of workers. If the state is a major distributor of land, these systems will be more deeply woven into the political and social relationships of the state and aristocracy.

Scholars have identified or at least suspected that most of these elements were present in Babylonia. Therefore, this paper presents an opportunity to test the Nieboer-Domar hypothesis by broadly examining the cuneiform record to underscore the labor element of the hypothesis. Pervasive labor shortages have been suspected for some Mesopotamian cities, Nippur in particular, and this paper attributes them to well-known population shifts but also, at the same time, to unstudied, systemic socio-biological forces. These forces kept natural population growth at near zero and susceptible to demographic shocks, made it difficult to recover from regional trauma, generated a large number of vulnerable subgroups, and perhaps limited or affected the need for men to seek wage employment. In times of demographic stress and depopulation, the Babylonian labor pool in the aggregate would have been a limited and barely renewable resource; and political institutions and elites would have pursued the familiar strategy of placing local and immigrant workers into servile systems to get work done. Babylonians were aware of this reality, and their understanding of these powerful forces and their effects made their way into multiple genres of texts. This paper therefore also offers an explanation for the persistence of servile systems over long periods of time, something that Nieboer-Domar never directly addressed.

Morbidity is an important topic in this discussion, and there is a rich and complex cuneiform record concerning Mesopotamian medicine and disease. Its interpretation is controversial, especially concerning the identification of ancient diseases (retrospective diagnosis). We could merely accept that Mesopotamians recognized the significant effect that disease played among the population and leave the matter at that. By doing so, we would not have to engage with the uncomfortable uncertainty of disease and medical texts. This would place an unfortunate check on our discussion, and so the present paper goes the other route and engages more expansively with the cuneiform record by considering the possible ways that Mesopotamian medical texts and incantations might reflect on the major limiters to mortality in Babylonia. 
The work presented here can also be added to the handful of publications searching for basic demographic measures in the cuneiform record. Postgate urged such endeavors over twenty years ago (1994b: 63-4), but few scholars have attempted to follow his lead (Galil 2007, Gehlken 2005, Tenney 2011b). Gathering Mesopotamian population data from native sources is of great value because all Mesopotamian scholars must operate in a research environment that now includes better means of evaluating the economy and more importantly has been gifted an unprecedented picture of Mesopotamian aggregate settlement through archaeological surveys (Jursa 2010; Adams 1981; Adams and Nissen 1972; Wilkinson et al. 2012, 2014; Ur et al. 2013). Archaeologists have observed significant swings in the fortunes of some areas in these surveys. The greatest of these was the supposed depopulation of urban areas in the Mesopotamian south beginning during the reign of Samsuiluna, which has only been half-heartedly explained as a result of a change in river courses. The earliest attempts to assemble the test population began not long after this. Future research might address how resilient the Mesopotamian population would have been during these crises, upheavals, and wars; because it is possible that demographic realities might have greatly extended the length of time required for a region to rebound. Settlement data also provides a window into aggregate population analysis (Sbonias 1999: 219, 228), and cuneiform texts may help with that effort by providing the population structure, demographic variables, and mechanisms that both spurred change and maintained stability.

The sources for the test case are over 500 cuneiform documents from the central Babylonian province of Nippur, whose function was to track and administer a population of as many as 8000 people. Historically speaking, these texts date to the Middle Babylonian/Kassite Period or more generally the Late Bronze Age (Tenney 2011a). They are typical bureaucratic records, which means that they use specialized language and contain few prosaic statements about their actual function. The information is conveyed in data-dense formats, notably tables, which further obscure their function and make them more difficult to describe with standard Assyriological terminology. Despite these shortcomings, the data they contain make it clear that several thousand people worked for the government of Nippur as servile workers during the height of the Kassite dynasty and after a period of hypothesized depopulation. Little is known about their personal residences, but the state parceled them out to elites, estates, and institutions and some of them seem to have been moved throughout the 
countryside. There are hints in the Babylonian written record that this servile system may have been used broadly throughout the kingdom. Many aspects of their lives have already been published in detail (ibid.), and the present paper uses new data in an effort to explore aggregate population behavior and servility more broadly.

The records are not perfectly suited to our purposes. There are the normal chronological problems, source damage, and the sorts of potential sampling and other issues common to early records that were never intended to be used as a proxy for modern census data (ibid.: 39-47; Bagnall and Frier 1994: 40-52). Nevertheless, given a few reasonable assumptions, ${ }^{14}$ the records can be an important tool in assembling a more comprehensive view of the pressures of servile life and Babylonian life in general. Because of its size and detailed recording apparatus, it could be the richest data set available for any Mesopotamian population. Extensive data from other periods might exist, but it would have to be processed in a way that makes quantitative study possible.

\section{$3 \quad$ Babylonian Populations}

Our exploration begins with a discussion about ancient populations for two reasons. First, there is a growing interest in populations and population dynamics in Assyriology, and we should assemble population data on Mesopotamian people whenever possible. These data would include variables concerning the ages at which crucial phases of life occur, e.g., weaning, marriage, death, fecundity, and length of childbearing years. Second, these same population variables are a crucial factor in establishing population levels, the size of the labor pool,

\footnotetext{
14 First, that the Middle Babylonian data set represents a quantifiable subpopulation which is free of unsurmountable sampling issues. Second, that this population was normal or followed normal, social rules as best as possible. By this I mean that it emulated the behavior of the standard population and was not affected by significant external forces, such as massive declines in fertility, brutal military campaigns, or a crisis of basic survival that affected only some generations of the population. At present, there is no direct evidence for this other than the percentages observed among the sex-age categories (particularly with sex ratios), but these could be due to other factors (sections 5-7). Third, that these texts can be used as a close approximation of a census, or that they may serve the same function for application purposes. For some of the discussion, one must assume that the personnel listed in the statistics have for the most part grown up in the system. If any of these assumptions are inaccurate, then some of the following conclusions will need to be revisited.
} 
and extent of settlement and available land. All of these matters are crucial to the Nieboer-Domar hypothesis.

In the case of Babylonia, the written record as currently understood has yet to produce an obvious census, nor does it provide the ages of people (Roth 1987: 716-7) thus affording little hope of advanced demographic study of the population. Historically, governments conducted a census in order to calculate wealth and taxes, military strength, or to allocate political representatives. None of these practices seem to have been in place in the region. ${ }^{15}$ Babylonian scribes also chose not to record ages in years for people, thus making it difficult for us to calculate important population variables and analyze historical trends. Settlement surveys provide a gross estimate of the material remains left by human residential activity but at present cannot provide a concrete sense of the size and composition of the population without major assumptions for key demographic variables. To date, most studies on Near Eastern populations have been restricted to calculations of settlement area or percentages and totals of people (Roth 1987; Postgate 1994b; Schloen 2001; Faust 2007; Tenney 2011a), which are simple descriptive statistics and not the sort of sophisticated demographic measures such as crude birth rate, general fertility rate, and infant-mortality rate which permit the study of trends. For this reason, references to "demography" or "demographic" studies in Mesopotamian scholarship can be misleading. ${ }^{16}$

\section{Separating the Variables: Mortality, "Natural Increase", and Migration}

Population levels are determined by fertility, mortality, and migration. Most of the ways in which these variables are measured are through averages, and measures derived from micro-studies - say, from legal texts produced for the landowning elites-may not agree with those gleaned from much larger data sets, such as those compiled from hundreds of work rosters. They are also less useful for the sort of questions being asked here. Mortality, which measures the fre-

15 Neo-Assyrian texts concerning estates in Harran were once labeled a census, but the function and coverage of these texts are now disputed (Fales and Postgate 1995: XxXIIXXXIII). Censuses of limited scope have been posited for Ugarit and Alalakh (Vidal 2014; von Dassow 2008); but the only clearly attested, mass, regional, censuses of population in the ancient world are found in areas under Greek or Roman control (Bagnall and Frier 1994; Clarysse and Thompson 2006). These same areas also supply records (often these same censuses) of people in years, often featuring age-rounding.

16 "Paleodemography," which includes a much broader range of methods and topics, is probably a more appropriate word (Sbonias 1999: 1). 
quency of death, is the primary focus of this paper for three reasons. One, historical demographers believe that before the great demographic transition, the birth rate was constant but the death rate was variable (Coale 1974: 23). Two, there is a great deal more mortality research from other pre-modern regions that can be used for comparison. Three, it is easier to achieve some sense of mortality in Babylonia from the cuneiform record for the reasons mentioned above and in this paper. For different reasons, fertility, the production of offspring, and migration, the movements of people, are very difficult to quantify for Babylonia. Population structure refers to the distribution of individuals across certain categories (Chamberlain 2001: 259). In the case of Mesopotamia, these categories are restricted to sex and obscure categories combining sex with age found in the cuneiform record (Section 5). Changes which can affect the size of a population or changes in its structure are considered population dynamics (Sbonias 1999: 219; Chamberlain: 259).

One must also separate the concept of natural population increase or decrease, which compares births to deaths, from total population increase or decrease, which factors in migration. Settlement survey experts have led the discussion on Mesopotamian population dynamics over the longue durée and have been vocal about their limitations. They have been clear that settlement data is merely proxy data for populations, and have calculated actual population data and chronological trends with these data (Wilkinson 1999). Some scholars feel that settlement survey data is fraught with methodological problems and strongly argue against making population estimates from survey data (Chapman 1999: 65; Chamberlain 2001: 259, 265).

\section{Applications to Babylonia}

The broad consensus among all historical demographers, especially those of the ancient and medieval worlds, is that pre-modern populations experienced high birth and death rates. Classic demographic transition theorists would deem this a high balance mortality situation (Friedlander, Okun, and Segal 1999: 495). They base these conclusions on statistics, theory, and model life tables assembled from populations deemed to be similar in essential characteristics. Model life tables (MLTS) predict the percentages of a population within specific age ranges given certain demographic parameters, such as mortality and fertility. They model closed populations and employ the concept of stable populations - or populations that are increasing or decreasing at a constant rate. It can take several generations for stability to manifest in a population after experiencing significant change (Chamberlain 2001: 260), which is germane to the shifts observed in Babylonian settlement. They are the best tool presently available to predict ancient phenomena (Hin 2013: 110), even if they 
do not factor in migration (Sbonias 1999: 231). They have been instrumental in evaluating important census returns from ancient Egypt (Bagnall and Frier 1994), but have never been used in conjunction with actual Mesopotamian population data. Schloen noted their potential fifteen years ago but lacked a viable data set to implement them (2001: 123), and more recently the M.A.s.s. project used MLTs to model urban development in northern Mesopotamia (Christiansen 2013: 164).

The standard best-fit MLTs for ancient Egypt have been Coale and Demeny Model West 4 for men and Model West 2 for women (Bagnall and Frier 1994: 35, 101). These tables are somewhat artificial in that they were designed for "underdeveloped countries where there is no reliable guide to the age pattern of mortality that prevails" (Coale and Demeny 1966: 29). Recently, several new tables were proposed as better predictors of the mortality patterns and disease ecology of the ancient world (Hin 2013: 109-23). They are derived from real surveys of people who lived in early twentieth-century Taiwan and Chile and different regions of Africa in the late twentieth century who had limited to no access to modern medicine and a disease ecology deemed more similar to the ancient world (INDEPTH 2004; Woods 2007). They differ from one another in rates of adult mortality and the presence of diseases, ailments, and epidemics that disproportionately affect certain age segments of the population (Figure 2). There is no consensus on which model to use with ancient data, although all of the new tables were a better fit to the census returns of ancient Egypt and Ulpian's table than Model West (Hin 2013: 109-24). None of them invalidate the standard Coale and Demeny average life expectancy, but they do change where one sees the major bumps and dips in mortality.

If we extrapolate from these analyses to Mesopotamia, we expect that the major health issues affecting mortality were childbirth, ${ }^{17}$ infected animal products, dysentery, fevers, and diseases like malaria, syphilis, and tuberculosis. Some of these diseases had seasonal patterning and/or disproportionately affected people of certain ages. Tuberculosis was a likely major cause of death for people between the ages of 15-45, while malaria and diarrhea were notable killers of children. Survival rates can only be roughly approximated, but it is certain that epidemics and chronic diseases had significant effects on daily life and productivity, and it has been estimated that people might spend up to a sixth of their life being too sick to work. In the records of the test population, sick workers are distinguished with a generic marker of illness (GIG). These texts cover periods of time of a month or more, indicating that similar long

17 The effects of childbirth on the mortality of women may be overestimated (Hin 2013: 129-30). 


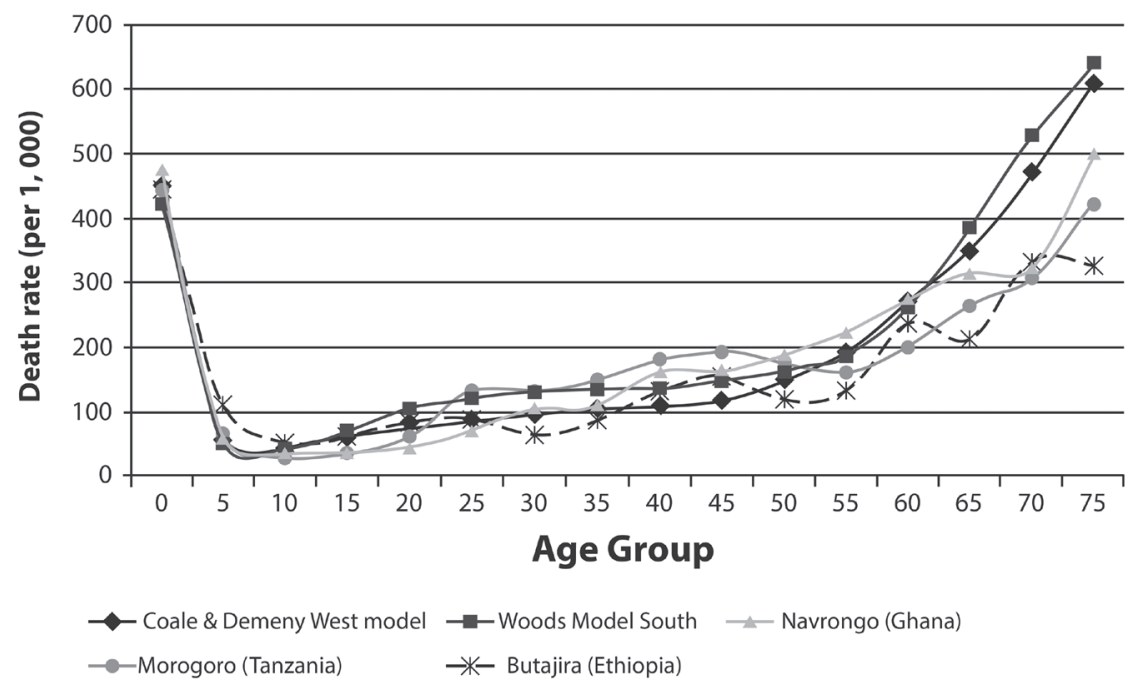

FIGURE 2 "Age-specific death rates (nqx) per 1,ooo: Coale and Demeny Model West, Woods Model South, and African Models compared" (Hin 2013: 113, redrawn by the author).

periods of incapacity are attested in Babylonian texts and were of concern to the government.

\section{Morbidity and Medical Texts}

Morbidity is a term used by demographers to describe the relative state of disease in a population. Cuneiform medical texts contain extensive references to physical symptoms and technical terms that identify illness and offer an opportunity to discuss Babylonian morbidity. Scholars have assigned modern disease names to the terms that supposedly identify diseases in ancient texts, a method known as retrospective diagnosis. Scurlock and Anderson identified all of the diseases previously mentioned as likely contributors to mortality in the prognostic/diagnostic medical compendia of Babylonia. These texts were compiled in the late second millennium and likely existed in some form at the time of our servile population (Scurlock and Andersen 2005: 6-7). Further correlates can be found in incantations meant to combat the effects of these diseases (Foster, B. 2005: 177, 184-5, 971-5).

Retrospective diagnoses have been greeted with skepticism and even disavowed by many Assyriologists (Rutz 2011: 299). These skeptics are the majority party in the debate over medical texts, and they cite many reasons for their opposition (Heeßel 2004: 5-7). For instance, they argue against retrospective diagnoses on methodological grounds rooted in the general uncertainty of the 
cuneiform record. Ancient subjects and expertise cannot be diagnosed with modern tools and medical equipment, therefore the retrospective diagnoses cannot be verified. This is an important point and in some ways echoes my own comments about the limitations of the lexical approach in dealing with servility. On the other hand, the translations used in retrospective diagnoses also cannot be proven false for the same reason that they cannot be proven true-an unfortunate evidentiary impasse. Opponents of retrospective diagnoses also point out that diseases evolve and go extinct, and one cannot assume that the disease ecology of today is the same as it was it the past. This is likewise significant, but scholarship from outside the field of Assyriology has questioned the severity and even the validity of these complaints (Cohen 1989: 37-38; Roberts and Manchester 2005: 14). Those who are skeptical of retrospective diagnoses have pointed out that human remains and bioarchaeology, not Mesopotamian medical texts, are the best means of recognizing illness in the ancient world. However, they too have their limits. Soft tissue-where information on disease is likely to be found-is rarely preserved. Skeletal remains only possess a very limited amount of information about the symptoms of some diseases, some of which can be attributed to more than one illness (ibid. 167). Moreover, the diseases that can be identified from skeletons are not among those believed to be great contributors to ancient mortality. That said, as each year passes and laboratory work improves, more is being learned about ancient disease. This process has revealed that many of the diseases that are suspected to have made up the most dangerous aspects of the ancient disease ecology (and identified in retrospective diagnoses) were in fact present in the ancient world, e.g., malaria, small pox, polio-myelitis, pneumonia, syphilis, tuberculosis, parasitic worms and parasites, etc. (Zimmerman 2008; Ortner 2008; Marciniak et al. 2016).

I profess no allegiance to either camp, but a middle ground focusing on the subjective experience of symptoms could be a profitable means of reflecting on morbidity (Robson 2008: 461). Since the chief concern of this paper is the identification of symptoms, rather than diagnoses, then it is at least worth considering the symptomatic descriptors provided in Mesopotamian medical texts. Most of the diseases, infections, and parasites that are most applicable to this study share many of the same symptoms (dysentery in particular) and words used to describe these symptoms have been clearly identified in medical texts. I have included a selection of passages from medical texts and incantations in Addendum 1 (examples 11-15), with the retrospective diagnoses given in parentheses, lest I be accused of falling into the same lexical trap I argued against in the introduction. 
Cholera, infected food, and other ailments can cause intense intestinal distress and even death in the developing world, and there is evidence that they were similarly great contributors to mortality in Babylonia. The parasites at the root of some of these afflictions have been observed in the archaeological record (Anastasiou and Mitchell 2015: 139-41). Babylonians recount being plagued by gastroenterological difficulties and described them in elaborate detail and with multiple terms. For example, gastric distress may have been described as "sick insides". Dysentery and diarrhea were an area of particular focus, and their descriptions ranged from the general and inconvenient (șubburu, șanāhu, and "loose bowels") to excruciating, voluminous, and deadly ("pouring out" and "flowing bowels") (Scurlock and Andersen 2005: $19,49-53) \cdot{ }^{18}$

Fevers were evaluated on a scale of severity with higher levels predicting imminent death. Malaria, tuberculosis, and problems of the lungs must have also been of great concern (Scurlock and Andersen 2005: 29, 36-7, 47). Garbage, sewage, and animals in the vicinity of the home and community were seen as health risks and in need of control (ibid.: 14-7, 21). Cuneiform sources make it clear that Mesopotamians were aware that contagion could devastate families and cause the abandonment of entire towns (Scurlock and Andersen 2005: 20; Addendum 1, examples 16-17). Both the Babylonian and the Romans developed elaborate drainage and sewage systems, yet they remained mostly powerless against the diseases, parasites, and infections of their environment (McMahon 2015; Mitchell 2015). It is believed that settled life may have reduced the number of diseases affecting a population, but increased the impact of contracted sickness. We can only conclude that a defining characteristic of Babylonia, its urbanism, was also one of the main contributors to the mortality of its inhabitants.

\section{Vulnerable Groups}

Babylonia was also a very young world. At least a third of the population was under the age of fifteen and a mere seven percent was over sixty. In today's developed nations, the same groups comprise around nineteen and twenty-one percent of the population, respectively (Parkin 2013: 41-2). For children in this environment, death was as much a part of daily life as it was for the elderly. Measures of mortality indicate that for every 1000 children born in a given year, a minimum of 300 would be dead before they finished the first year of life. By age five, about half of them would still be alive (ibid.: 46-7). Children younger

18 Șubburu ("to get diarrhea"), șanāhnu ("to have diarrhea/defecate"), (CAD 16: 3-4, 96). 
than ten years old had mortality rates three or four times higher than people over the age of sixty, but those who survived the early years of life and made it to age five could expect to still be alive at forty (Scheidel 2007: 40). A high mortality level among the young is present in all MLTs mentioned earlier, and circumstances were likely the same in Bronze Age Babylonia.

The mortality regime would have produced a high incidence of widows and orphans (ibid.: 41), and some monarchs recognized this harsh aspect of Babylonian life and sought to protect them. The Reforms of Uruinimgina and The Laws of Ur-Namma have royal declarations of safeguarding for widows and orphans (Fensham 1962: 130):

Examples 1-2. Reforms of Uruinimgina, Ruler of Lagash and Laws of Ur-Namma, Ruler of Ur.

Uruinimgina pledged to Ningirsu (a god) that he would never hand over the orphan and the widow to the powerful.

COOPER 1986: 73; FRAYNE 2008: 264-5

I did not deliver the orphan to the rich. I did not deliver the widow to the mighty.

ROTH 1997: 16

The financial circumstances of widowed women in Babylonia could be precarious, especially if the widow had no male children, which would mean that she would no longer have any blood relations who could inherit from her husband's estate. Law codes of Babylonia and Assyria protected her dowry, marriage gifts, and home from her husband's brothers or sons from another wife, so she would have a future means of support. They also provided the means for communities to evaluate any exceptional circumstances and provide aid (ibid.: 114-6, 170-1). A widow without such resources might find herself in financial ruin and an easy target for temporary debt-bondage or entrance into institutional servility. She might even sell her herself or her children into permanent slavery (Oppenheim 1955; Petschow 1983; Steinkeller 2002).

\section{Challenges to Growth}

Observed life expectancies at birth of preindustrial people rest between twenty to forty years, and twenty-five is often used as a "convenient mean" (Hin 2013: 106). This is not to say that survival rates for age groups were consistent and that people were incapable of making it well into old age. The repercussions of different mortality and fertility conditions would lead to wildly different historical scenarios: 
When life expectancy is around 20 at birth, adult women need to have about 3.2 daughters born alive (and another 3.2 sons) on average to keep the population stationary. At a life expectancy that low, the so-called Gross Reproduction Rate required for demographic survival of a population is close to the range of 4.0 and above that is considered highly unlikely, if not impossible, to maintain. When life expectancy is 40 , the population will remain even across the generations when adult women have 1.7 daughters on average, and 3.3 children altogether. If adult women had 6.4 children under this mortality regime, population would grow by $2.25 \%$ annually rather than by $0 \%$, and double its size in about 30 years.

HIN 2013: 104

In comparison, women in the developed world bear an average of 2.05 healthy children, and Western populations are now returning to near zero growth levels after a demographic explosion caused by drastically reduced mortality and dramatically increased fertility because of changes in medical science and breastfeeding practice (Hin 2013: 172; Friedlander, Okun, and Segal 1999: 494; Habicht et al. 1990: 213-4, 231-3). Conjugal families among our servile population had an average of 2.7 children, which is one indication of minimal growth and a possible harbinger of demographic insecurity. If one considers the statistics for all recorded workers regardless of marital or familial status, the prognosis of growth for these workers is bleak because few families are recorded and the sex ratios heavily favor males. ${ }^{19}$

Based on statistics, observations, and models, historical demographers have come to the consensus that human populations saw between 0.00 and 0.05 percent growth each year until the demographic transition began in the eighteenth century (Friedlander, Okun, and Segal 1999: 494; Scheidel 2007: 41; Hanley 1974: 141). Until now, Mesopotamian scholars have been using a somewhat higher measure, 0.1, and I have included a second addendum in this paper where I trace the thinking behind this proposed figure as best as I can (Addendum 2). Both the higher and lower rates of population growth rely on a number of assumptions and incomplete evidence, but I would argue that the origins of the 0.1 measure make it more difficult to accept. Moreover, the scholars who initially proposed it never intended it to be used in the manner it is being employed today. The data used in the analysis of most MLTs has at least been observed among real, past populations. In addition, the larger measure of 0.1 refers to continental and worldwide growth over very long periods of time.

19 There are different ways to interpret observations of low numbers of families, children, and adult women in the data set, some of which mitigate this statement. 
Because of these measures of growth and other indicators-family size, life expectancy, age at first marriage, etc.- it has been decided that "reproduction under normal conditions" in the ancient world was "barely possible" and major epidemics and extensive wars could bring demographic catastrophe (Hin 2013: 101). It would have been extremely difficult for regions to recover from such trauma through natural growth alone. ${ }^{20}$ On a smaller scale the recovery could be quicker, and small, localized areas might be able to experience dramatic shifts in growth or decline over the course of a century, but not much beyond that (ibid.; Friedlander, Okun, and Segal 1999: 494; Scheidel 2007: 41). As a consequence, the fortunes of cities would have been dependent on their ability to draw people from other parts of Babylonia or from regions further afield.

Growth in settlement area at levels proposed here, and growth suspected to be caused by intra-regional population shift have been proposed from proxy data from different parts of Mesopotamia. If accepted, they would confirm the conclusions derived from documentary evidence and models just mentioned (Altaweel 2013: 262; Wilkinson, Ur, and Hritz 2013: 50). Unfortunately, there is no certain way to separate growth as a result of natural increase and decrease from that caused by migration. Migration from localized regions (e.g., from city to city) versus migration over longer distances also cannot be quantified with current evidence. Both of these situations hamper further understanding and undermine the veracity of these proposed population shifts. Survey data may also substantially overestimate the contemporaneity of sites because all pottery left on a site dating to particular period need not be deposited at the same, exact time. This would conflate population shifts from short-term and short-distance migration with population growth over a larger region and longer period of time (Chapman 1999: 69, 74). The major implication would be that population size and changes in population size are overestimated from archaeological proxy data.

Nonetheless, we can be confident that Babylonia experienced fertility and mortality patterns that were similar to the rest of the pre-modern world. The reservations mentioned above underscore the need for more precise data drawn from the cuneiform record. Native data should be gathered and used to derive as many demographic values as possible. This would lessen our reliance on comparative data and add some granularity to our discussions of proxy data, especially concerning population dynamics. This is especially important for measures concerning women, because their fertility and mortality determine the trajectory of a population. One could also develop the data permitting a 
best-fit calculation with an existing MLT or even to generate a Babylonian MLT. Apart from burials, the bureaucratic records of servile systems are the most likely place to find these baseline metrics. Data points drawn from documents in the literary or royal realms could be of use, but they tend to reflect idealized rather than real behavior (Levy 1965: 7-12; Hin 2013: 104, 178-9).

A knowledge of age is the biggest challenge to overcome as it is required for nearly all demographic measures (Tenney 2011a: 145-6). The recording of ages for humans is rare in cuneiform documents, and we instead must rely on a series of administrative categories of sex and age. These classifications have ancient origins (Bartash 2015), are ubiquitous in bureaucratic texts of all periods, and their logographic representations have great endurance in Babylonia. ${ }^{21}$ For this reason, there are also geographic and diachronic differences in the number and character of designations.

There is little understanding of what these categories represent in terms of actual age in years. Their only clear function in Kassite Babylonia was to serve as means of calculating food payments - the older a person was, the more they were allocated - but some of the categories speak to real behavior (Section 6). A selection of some of the categories is provided in Figure 3. English translations for some of the Middle Babylonian categories are mere approximations. The youngest categories are also used to classify cattle in administrative records from multiple periods. ${ }^{22}$

21 Comparable age categories can be found in a Biblical passage dealing with votary pledges of human beings to the temple. A passage in Leviticus 27: 3-7 separates males and females into four groups and provides monetary substitutes for each: 1 month- 5 years, 5-20 years, 20-6o years, and 6o plus years (Milgrom 2000: 2370-1). This observation is courtesy of J.A. Brinkman, assistance by Lauren Monroe.

22 In some monumental art, captive people and cattle are portrayed in similar circumstances and imagery (Ataç 2010: 46). Instances of slave and cattle branding in the same period have been noted (Foster 2010: 148). 
MALE

\begin{tabular}{|c|c|c|c|c|c|}
\hline Akkadian & Ur III & $\begin{array}{l}\text { Old } \\
\text { Babylonian }\end{array}$ & $\begin{array}{l}\text { Middle } \\
\text { Babylonian }\end{array}$ & $\begin{array}{l}\text { Middle } \\
\text { Assyrian } \\
\text { (varies) }\end{array}$ & Neo-Assyrian \\
\hline (GURUŠ.)ŠU.GI 4 & GURUŠ.ŠU.GI ${ }_{4}$ & ŠU.GI & ŠU.G I (old) & & \\
\hline \multirow[t]{2}{*}{ GURUŠ } & GURUŠ & GURUŠ & GURUŠ (adult) & $\begin{array}{l}\text { LÚ / ša šipri } \\
\text { (full-aged } \\
\text { worker) }\end{array}$ & (ikkaru?) \\
\hline & & & $\begin{array}{l}\text { GURUŠ.TUR } \\
\text { (adolescent) }\end{array}$ & $\begin{array}{l}\text { (Lú) talmīdu } \\
\text { (apprentice) }\end{array}$ & $s ̦ a<h u r t u>$ \\
\hline $\begin{array}{l}\text { DUMU.NÍTA } \\
\text { (sons) }\end{array}$ & $\begin{array}{l}\text { DUMU.NÍTA } \\
\text { (boy) }\end{array}$ & TUR (boy) & $\begin{array}{l}\text { GURUŠ.TUR. } \\
\text { TUR (child) } \\
\text { pirsu (weaned) }\end{array}$ & $\begin{array}{l}\text { (LÚ) tari'u } \\
\text { (youngster) } \\
\text { (LÚ) pirsu }\end{array}$ & $\begin{array}{l}\text { by rūṭu, span } \\
(3 / 4 / 5) \\
\operatorname{pir}(s u) / \text { UD }\end{array}$ \\
\hline DUMU.GA/GABA & DUMU.GA/GABA & $\begin{array}{l}\text { DUMU.GABA } \\
\text { (baby) }\end{array}$ & $\begin{array}{l}\text { DUMU.GABA } \\
\text { (nursing) }\end{array}$ & $(\mathrm{LU}) \check{s} \check{s} a \mathrm{GABA}$ & $\mathrm{GA}$ \\
\hline
\end{tabular}

Female

\begin{tabular}{|c|c|c|c|c|c|}
\hline Akkadian & Ur III & $\begin{array}{l}\text { Old } \\
\text { Babylonian }\end{array}$ & $\begin{array}{l}\text { Middle } \\
\text { Babylonian }\end{array}$ & $\begin{array}{l}\text { Middle } \\
\text { Assyrian }\end{array}$ & Neo-Assyrian \\
\hline (GÉME.)ŠU.GI 4 & GÉME.ŠU.GI 4 & SAL.ŠU.GI & $\begin{array}{l}\text { SAL.ŠU.GI } \\
\text { (old) }\end{array}$ & & \\
\hline GÉME & GÉME & SAL & $\begin{array}{l}\text { SAL (adult) } \\
\text { SAL.TUR } \\
\text { (adolescent) }\end{array}$ & $\begin{array}{l}\text { SAL } \\
\text { (SAL) talmittu } \\
\text { (apprentice) }\end{array}$ & $\begin{array}{l}\text { SAL } \\
\text { batussu }\end{array}$ \\
\hline $\begin{array}{l}\text { DUMU.SAL } \\
\text { (daughter) }\end{array}$ & $\begin{array}{l}\text { DUMU.SAL } \\
\text { (girl) }\end{array}$ & $\begin{array}{l}\text { SAL.TUR } \\
\text { (girl) }\end{array}$ & $\begin{array}{l}\text { SAL.TUR.TUR } \\
\text { (child) } \\
\text { pirsatu }(m) \\
\text { (weaned) }\end{array}$ & $\begin{array}{l}\text { (SAL) tārītu } \\
\text { (youngster) } \\
\text { (SAL) pirsu }\end{array}$ & $\begin{array}{l}\text { by rūṭu, span } \\
(3 / 4 / 5) \\
p i r(s u) / \text { D }\end{array}$ \\
\hline DUMU.GA/GABA & $\begin{array}{l}\text { DUMU.GA/GABA } \\
\text { DUMU.SAL.GABA } \\
\text { (baby) }\end{array}$ & $\begin{array}{l}\text { DUMU.SAL.GABA } \\
\text { (nursing) }\end{array}$ & $(\mathrm{SAL}) \check{s} a \mathrm{GABA}$ & GA & \\
\hline
\end{tabular}

FIGURE 3 Select sex-age categories in cuneiform records, test case in Center (Bloch 2008: 159-64; Bridges 1981: 36; Galil 2007; Gelb 1965; Seri 2013; Studevent-Hickman 2006; Roth 1987; Salah 2014; Tenney 2011a). ${ }^{23}$

23 Published translations are given in parentheses if different from the Middle Babylonian period. For attempts to assign age ranges for Assyrian designations, see Bloch (2008: 161). 
In the Middle Babylonian period, it seems that some categories are related to important milestones in a person's life, such as the age of weaning, or the entrance into adulthood and subsequently into old age. M LTs predict the percentages of a population that fit within particular age ranges, e.g., twelve percent of the population is four years of age or younger. If the percentage of the total population belonging to a sex-age category is known, then an age range can be assigned for each category and one can set benchmark ages for these events (Figures 5-6). This is a simple methodology with coarse results, but the results are supported by cuneiform and comparative evidence. At present it offers our only hope of establishing any age patterns from a data set of respectable weight, and is merely an initial step towards better (or any) population metrics. ${ }^{24}$ Middle Babylonian servile workers have the following age distribution:

\begin{tabular}{lcccc}
\hline & \multicolumn{2}{c}{ Males } & \multicolumn{2}{c}{ Females } \\
& $\begin{array}{l}\text { Percentage } \\
\text { of Males }\end{array}$ & $\begin{array}{l}\text { Percentage in } \\
\text { Category and } \\
\text { Younger }\end{array}$ & $\begin{array}{l}\text { Percentage } \\
\text { of Females }\end{array}$ & $\begin{array}{r}\text { Percentage in } \\
\text { Category and } \\
\text { Younger }\end{array}$ \\
& & 12.1 & 17.9 & 17.9 \\
Nursing & 12.1 & 19.0 & 5.9 & 23.8 \\
Weaned & 6.9 & 40.5 & 16.7 & 40.5 \\
Adolescent & 21.5 & 99.2 & 59.1 & 99.6 \\
Adult & 58.7 & 100.0 & 0.4 & 100.0 \\
Elderly & 0.8 & & & \\
\hline
\end{tabular}

FIGURE 4 Distribution by sex-age category.

There are alternative translations for tariu and tārìtu (Stol 2000: 190). The issue of space restricted the range of designations and bibliography presented in this figure, so it should not be considered as exhaustive. Some of the material excluded from the chart includes the earliest attestations of which I am aware (Bartash 2015), minor variations seen at Middle Assyrian Dūr-Katlimmu (Salah 2014: 3, 11-34), and sex-age designations found in Neo-Assyrian private documents, many of which are already given in Figure 3 (Radner 1997: 126-33, 147-52). Note the logographic readings of SAL.GURUŠ.TUR and SAL.TUR as batussu and their Babylonian correlates.

24 My thanks to Joshua R. Goldstein for suggesting this to me. At the time he was executive director of the Max Planck Institute for Demographic Research; he is now Professor at UC Berkeley. 
There are similar percentages in adult and weaned categories of both sexes, but there are clear disagreements between the sexes in other categories. ${ }^{25}$ If this were a normal population, the percentages for adolescent males and females should be similar, but the proportion of females among the nursing are five percent larger and five percent fewer among adolescents than among males (Tenney 2011a: 53-54). One could attribute some of the discrepancy to a dearth of infant males. Boys have higher infant mortality: indeed, in some parts of Africa it has been measured at $44 \%$ greater than females (INDEPTH 2004: 12). There is evidence of under-reporting of male children in ancient censuses, but the cause of this underregistration does not seem to be present for our Middle Babylonian workers, unless they were subject to some sort of tax (Bagnall and Frier 1994: 97-8). Also, a female population with eighteen percent breastfeeding girls is problematic. It seems that the problem lies in the female data.

\section{Missing Girls ${ }^{26}$}

Fales noted a similar absence of girls in the data assembled by Gershon Galil for his study on the "lower-stratum families" of Assyria. ${ }^{27}$ Likewise, Seri found more nursing girls and fewer older girls than expected in her study of old Babylonian prisoners of war (Seri 2013: 111-2). Fales calculated that girls were underrepresented by the same margin as observed in the test case data$4-5 \%$ less than normal. He blamed it on disturbing practices, stating that these girls had been "diverted to other destinations," that families were separated by social coercion, and there was "forced reduction of certain population groups" (Fales 2009-10: 181-2).

Like Fales, I have suggested in my own past publications with similarly disquieting causes for these statistics. Among the possible reasons I forwarded to account for the discrepancy for Middle Babylonian workers were selective infanticide, the selling of girls, and acts of violence or separation during capture. I also proposed benign explanations. Girls could have moved to a different household earlier because they found a husband, entered kallatu-status, ${ }^{28}$ or otherwise dropped out of the records. ${ }^{29}$ If the proposed age ranges for these categories are close to correct (Figure 6), then we would expect females to

\footnotetext{
25 In total numbers, males dominate every category except the nursing category.

26 For a dramatic, contemporary problem of missing girls in Asia, see Sen (1992, 2003).

27 Roth was the first to note this in the Harran census tablets, which were included in the corpus used by Galil (Roth 1987: 734-36).

28 A sort of pre-marriage arrangement.

29 Another potential reason might be an under-reporting of male infants, a strategy used by members of the Roman Empire to avoid taxes.
} 


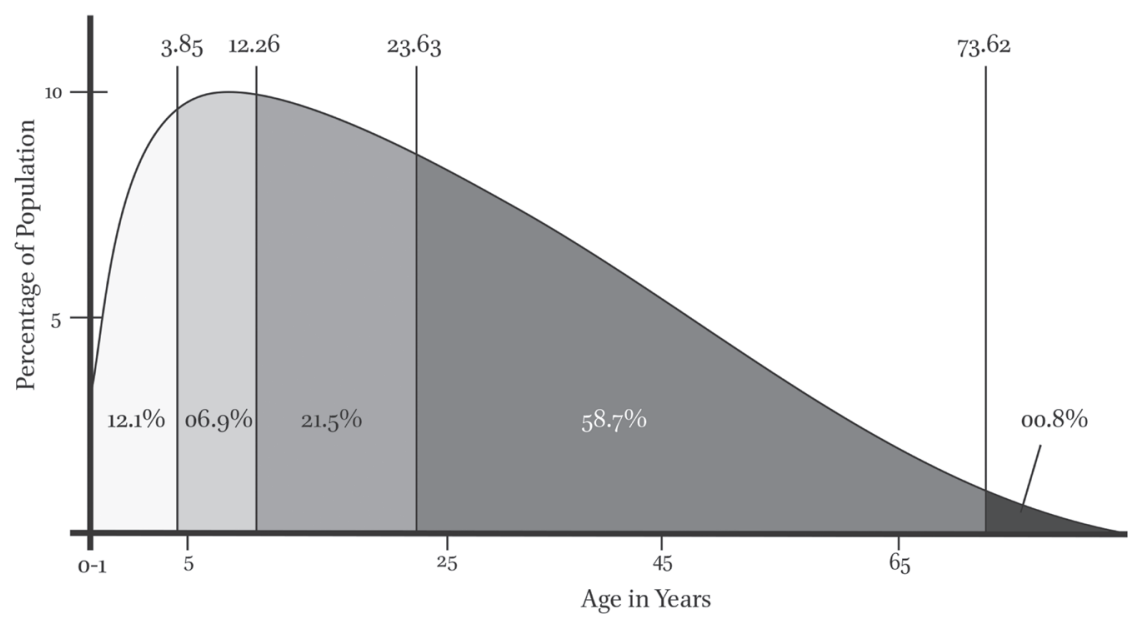

FIGURE 5 Explanatory figure of interpolation used to establish upper age limits, vertical lines indicate age limit cutoff.

move through the categories faster than males and would reach the category of "adulthood" at an earlier age than men. It is biologically desirable to nurse girls longer than boys, but this is rarely practiced (Detwyler 1995: 61; Granqvist 1947: 108). As we will see in the following paragraphs, it certainly affects the age range for nursing girls. There is also no evidence that people were sold out of the system, and there are a very small minority of women who are freed (zakû: Tenney 2011a: 31). Moreover, all attested kallatu and married women are in the adult category. If these girls are leaving to marry into other households, one would expect equilibrium to return in the adult category as new women married servile men. This seems to be the case, although the exchange is not equal.

The root causes for these missing girls are not our concern here. Since this discrepancy in female representation is present in multiple sources from different regions and time periods, then it is reasonable to assume it is a general feature of documents of this type. Based on these MLTs and assuming that mortality level was constant within MLT age groups, we can use linear interpolation to find the upper age limit of each of the Babylonian age groups. Therefore, we can achieve estimates of age ranges in years for each sex-age category (Figure 6). The methodology and thought process are explained graphically in Figure 5, which is only a heuristic tool, not a true indicator of the real data. Imagine that the entire area under the curve equals the entire population (99.999\%).

For the previously stated reasons, the cutoffs in the data do not accurately represent females. The distribution should be similar to males, so female age 


\begin{tabular}{|c|c|c|c|c|c|c|}
\hline & Males & & Age Category & & Females $^{\mathrm{a}}$ & \\
\hline shrinking & stable & growing & & shrinking & stable & growing \\
\hline $0-4.61$ & $0-3.85$ & $0-3.27$ & Nursing & $0-4.11$ & $0-3 \cdot 45$ & $0-2.91$ \\
\hline $4 \cdot 61-13 \cdot 3^{2}$ & $3.85^{-12.26}$ & $3.27-11.31$ & $\begin{array}{l}\text { Weaned/ } \\
\text { Children }\end{array}$ & $4.11-12.73$ & $3 \cdot 45^{-11.69}$ & $2.91-10.76$ \\
\hline $13 \cdot 3^{2-25} \cdot 3^{8}$ & $12.26-23.63$ & $11.31-22.07$ & Adolescents & $12.73-24.72$ & $11.69-22.98$ & $10.76-21.39$ \\
\hline $25 \cdot 3^{8-74.87}$ & $23.63-73.62$ & $22.07-72.31$ & Adults & $24 \cdot 72-74 \cdot 57$ & $22.98-73 \cdot 4^{2}$ & $21.39-72.17$ \\
\hline $74.87^{+}$ & $73.62+$ & $72.30+$ & Elderly & $74.57^{+}$ & $73 \cdot 42+$ & $72.17^{+}$ \\
\hline
\end{tabular}

a The cutoffs for females using female data and female MLT (Model West $2 \mathrm{R}=0$ ) are: 0-11.6/11.16-14.03/14.03-22.98/22.98-76.98/76.98+.

FIGURE 6 Estimates of age ranges (years) for sex-age categories under different growth parameters.

ranges were calculated using male percentages but with a female mortality table. ${ }^{30}$ One could replace the missing girls to the order of $5 \%$ observed by Fales to reach another estimation of the "normal" picture, but this correction is the same as making the female data replicate the male data. Accepting the distribution of females into the categories of males, one notes that females move through the categories faster than males, confirming my earlier tentative suggestions (Tenney 2011a: 57 ).

Calculations for the rest of the paper assume a stable population $(\mathrm{R}=\mathbf{0 . 0})$ that is neither growing nor shrinking, which is in line with the earlier observation of near zero population growth. If the system was closed, these numbers might need to be revised because our servile population may have shrunk over time. The evidence for this shrinkage includes the ratio of children to adults (o.67:1), boys to girls (1.07:1), and males to females (1.39:1, i.e., sex ratio of 139). This may have resulted in a population deficit, which is a result of higher death rate than birth rate (Hin 2013: 228). Moreover, parents were barely replacing their own numbers through births, and families are not common in the source documents. The administration itself recorded figures showing more losses than additions and went to some effort to reintroduce escapees into the system.

Age ranges for slightly shrinking and slightly growing scenarios have been provided numerically in Figure 6 and graphically in Figure 7 . If the population

30 Model West 4 for males, 2 for females, are the standard models for ancient populations and were used to keep bias constant. 


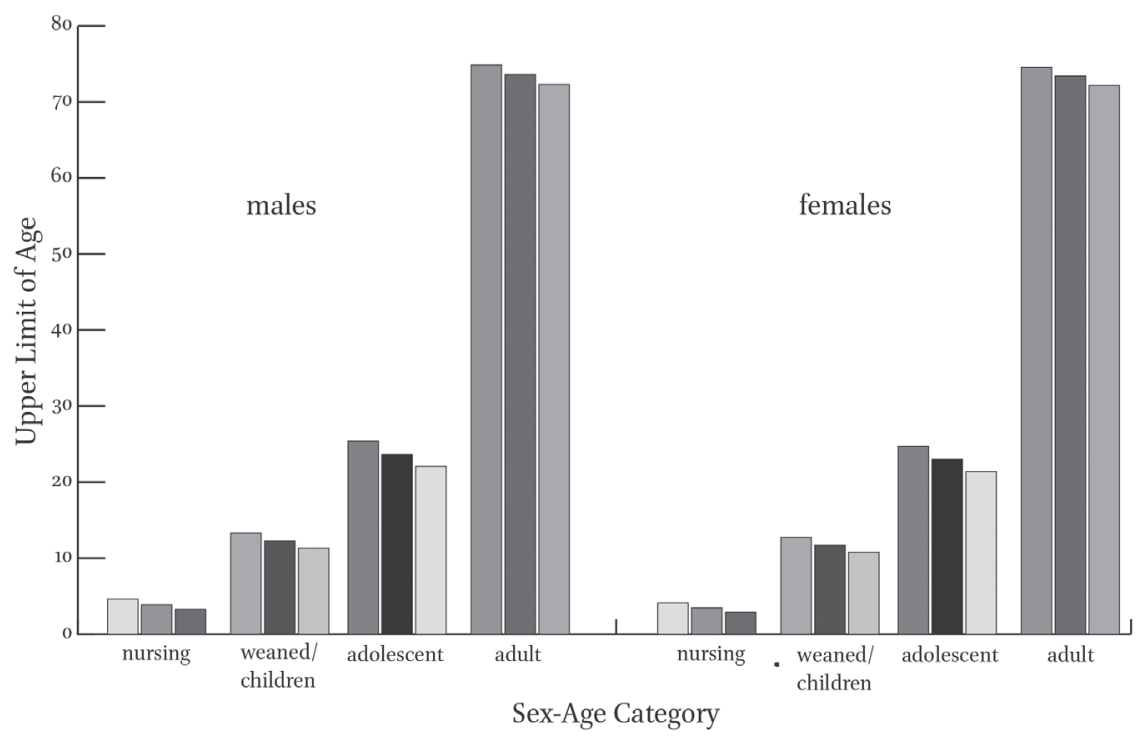

FIGURE 7 Differences in upper limits according to growth parameters. ${ }^{31}$

was getting smaller by a slight margin $(\mathrm{R}=-0.5)$, then we would have to raise the upper age limits for categories: the length of nursing category by about 10 months for males, a few months less for females and so forth (Figures 6-7). If the population were growing $(\mathrm{R}=0.5)$, then these numbers decrease by about six months. The reason in both situations is that one has to increase or decrease the upper limit in order to capture the known percentage.

\section{5} The Early Lives of Servile Children

The common translations of the categories DUMU.GABA and pirsu (feminine, DUMU.SAL.GABA and pirsatu) are "nursing" and "weaned." Literal translations are "son/daughter of the breast" and "severed (from the breast)," respectively. If taken literally, the transitions from DUMU.GABA to pirsu or DUMU.SAL GABA to pirsatu seem to have marked the end of breastfeeding. The calculations given here suggest that children may have breastfed to nearly the fourth year of life and perhaps beyond. It is theoretically possible that these categories were solely bureaucratic and should not be taken literally, especially in the case of children nearing the end of each phase. We must therefore be open to the possibility that the categories may have not been completely based on feeding

31 Left bar is $\mathrm{R}=-0.5$, center is $\mathrm{R}=0.0$, and right is $\mathrm{R}=0.5$. 
behavior. Pirsu/pirsatu could even be a reference to social separation from the mother. ${ }^{32}$ However, a brief foray into the process of weaning as expressed in ancient evidence and in more recent ethnographic studies will demonstrate that it is possible that the age ranges as calculated here may reflect ancient behavior.

\section{Weaning in the Ancient World}

Weaning is the process by which children are introduced to steadily increasing amounts of solid food to supplement the nutrients received through breast milk. Breastfeeding is gradually decreased until the child or parent decides that nursing will end (Herring, Saunders, and Katzenberg 1998: 425). Weaning is a milestone achieved through a progression of developments, and we should keep this in mind when we try to assign precise ages to its beginning and end. It is not a momentary event. Most experts agree that children can begin to eat solid foods in combination with breastfeeding as early as six months when milk teeth begin to surface (Fildes 1986: 12). Weaning any earlier than this brings health risks (Herring, Saunders, and Katzenberg 1998: 436).

Childhood nutrition and breastfeeding are not well-explored Assyriological topics. The assumption is that it lasted as long as the standard wet-nursing contract, 2-3 years (Biggs 2000: 6; Stol 2000: 181). Waetzoldt proposed that the nursing age group in the 21st-century ВСЕ lasted from birth to age five and believed the following age category lasted from ages five to ten. His methodology was fairly straightforward. Using a birth interval (space between offspring) of 1.5 years he counted forwards from each known birth point adding his birth interval between each known child until he reached the eldest (1987:133). Once a more realistic birth interval of 1.7 years is applied (See section 7), we find that nursing children in his documents stayed in this category until the age of around 4 years and 11 months - about a year older than our results. Gruber, who also argued for a later Near Eastern date for weaning, interpreted a passage from the book of Isaiah as evidence that weaning of Biblical children happened when they could be taught the alphabet and other knowledge (1989: 69). The us Department of Education has found that children are capable of identifying a few letters and making some letter-sound matches between the ages three and five. They may also be able to spell their name. After age five, most children will be able to write and work with the alphabet. ${ }^{33}$

32 It is surprising how close this division is to the point at which children's life expectancy dramatically increases. 
In Egyptian census returns from the Roman Period, infancy is deemed to end sometime before the age of five (Bagnall and Frier 1994: 35). Stable nitrogen analysis has been used on skeletons of children in a third-century AD cemetery in Dakhleh Oasis, Egypt, to show that on average children began eating solid foods around age six months and were weaned about age three- a weaning period of around 2.5 years (Dupras, Schwarz, and Fairgrieve 2001: 208). The standard period of Late Egyptian and Roman wet-nursing contracts was two to four years of service. Similar spans of time can be found in wet-nursing agreements in Mesopotamia (Parkin 2013: 55). Three seems to be the commonly accepted age of complete weaning in the Classical world. In recent centuries, wet-nursing was available to those rare few who could afford it, yet wet nurses in Rome and Babylonia were used to feed slave children who had been abandoned by their parents (Pudsey 2013: 488-9; Wunsch 2003/2004). The test population seems to supply wet nurses rather than employ them (Tenney 2011a: 231), and it is possible that they were contracted to nurse non-servile children or even to raise abandoned and/or servile children (ibid.: 86; Stol 2000: 182).

\section{Weaning in Historical Sources and Ethnographies}

A gradual introduction to solid foods as part of an extended weaning process can be observed among historically attested groups outside of the ancient Near East. ${ }^{34}$ Speaking generally, the duration of breastfeeding was determined by culture, wealth, environment, and level of modernization (Herring, Saunders, and Katzenberg 1998: 436, Akin et al. 1986: 257). Evidence for an average age of weaning from 3-6 years old can be found in past populations spanning from prehistory to the later nineteenth century (Wright and Schwarcz 1998: 15; Dittmann 2000: 345; Fuller et al. 2006: 47). A later age at weaning agrees within one year with the child/adult age division used by demographers working on sustainability in servile populations (Menard 1975: 38 ).

Further insight can be gained from studies done on weaning in Britain during its transition to an industrial society. The subjects of said studies were mostly urban and affluent and the data revealed that the transition towards earlier complete weaning in the first and second year observed in the West today happened in concert with England's increase in manufacturing and wealth. The use of wet nurses also expanded as a symbol of social status (Gruber 1989: 71-4). As this trend grew, some doctors in Britain continued to advocate for

34 Modern day studies on breastfeeding are often funded by infant formula companies, who have a profit interest in promoting the virtues and convenience of early weaning and bottle feeding (Detwyler 1995: 58-59). The World Health Organization recommends breastfeeding for at least two years. 
the earlier tradition, claiming that weaning as late as 36 months was preferable. A small sample of known ages at weaning over the same period indicates that many children were weaned according to the popular schedule of the new, industrializing society (by years 1-2); but that many families seem to have followed the advice of the previously mentioned medical professionals, allowing their children to breast-feed into their fourth year (Fildes 1986: $357^{-}$ 9). In more recent times, a study of 64 traditional societies gleaned from the Human Relations Area Files showed an average weaning age between 3-4 years old, but some groups extended it to age six or even age twelve (Ford 1945: 78). Other studies have argued that five years to complete weaning is not out of the ordinary and have uncovered ample evidence of weaning as late as seven, ten, or even fifteen years of age in parts of the Middle East and beyond, especially in extreme environments and circumstances (Wickes 1953: 151; Granqvist 1947: 247-8). A biological study has established that the healthiest age at weaning for humans should be between 2.5 and 6 years of age, slightly later for girls (Detwyler 1995: 61). ${ }^{35}$

\section{Weaning in the Test Population}

There are several reasons to suspect that Middle Babylonian servile workers, i.e., the test population, employed an extended weaning process. The evidence for this conclusion can be found in the Babylonian source texts from this particular period, and similar hints exist in texts from other periods. First, nursing children were given allocations of barley as food. In addition, the amount of food given to children in this category varied and included no payments at all. If the payments were scalar, this could be seen as a tacit recognition that a) the caloric needs of children via solid foods increased over time; b) the process of providing nutrition to weaning children included a mixed strategy of breastfeeding and solid foods; and c) nursing children become more reliant on solid foods as they aged. This hypothesis needs further testing. Second, there is evidence that servile women worked with their children in Babylonia, a common strategy for families with an extended weaning process (Seri 2013: 138; Tenney 2011a: 101). The children could be gradually introduced to the skills of their parents while being fed throughout the day, and the evidence demonstrates that children and parents in the test population were often employed in the same industries. In traditional societies that practice late weaning, nursing follows no schedule or nursing routine. Children are nursed whenever hungry, and the process is less onerous and time consuming in its later stages and allows for more non-child related labor (Ford 1945: 79). Deficiencies in a 
mother's diet are unlikely to affect the child because even very poorly nourished women "produce the same quantity and quality of milk for their infants as well-nourished women" (Detwyler 1995: 6o), so even the poorest infants in the population would have had adequate nutrition if their mothers were alive, reasonably healthy, and in close proximity. Third, in communities with late weaning, women would sometimes nurse multiple children, and almost nineteen percent of nuclear families in the test population had two breastfeeding children under their care (Tenney 2011a: 86). Lastly, nursing children in the test population worked as shepherds, weavers, and other occupations (ibid.: 101), and the economic utility of vulnerable children was exploited in other periods (Wunsch 2003/2004: 180-81). Among modern populations, international labor agencies have noted the common occurrence of child laborers as young as five, and journalists have reported workers as young as three years old. ${ }^{36}$

\section{Breastfeeding and Health}

For our servile people and Babylonians in general, long periods of breastfeeding would have had significant benefits. It would have protected a child from many of the problems that accompany weaning and early life, especially in a hot climate. These problems include iron deficiencies, food allergies, and infected animal products. Mothers pass on immunizations through their breast milk. Since children will not reach full immune competence until age six, longer periods of breastfeeding improve a child's chances against disease (Detwyler 1995: 56). Diarrhea was a major killer of children, and this problem would have been exacerbated by early weaning. The medical problems of infants and children were accorded their own tablet in a major medical diagnostic "handbook," and several statements refer to frightful diarrhea and dysentery (Scurlock and Andersen 2005: 386-7, 409).

Examples 3-4. Medical Passages Concerning Infants.

If an infant as soon as he is born sucks the teat, but does not get fat ... but pours out and his flesh diminishes, he was gotten 'by the dust."”

If an illness infects a child of one, two, or three months so that it keeps him awake day and night, his flesh (looks) terrible, his insides are cramped, his bowels are loose, and he is completely crushed....

IBID. 52,411

36 IPEC and SIMPOC 2002 and http://www.motherjones.com/media/2012/11/kids-bedrooms -james-mollison. 
Insufficient time on the breast leads to sickness and increased infant mortality, and once children begin to walk and socialize, the child's health became a community-wide concern, especially when it comes to parasites and dysentery (Hin 2013: 95, 128; Ford 1945: 84). Weaning is stressful for a child and the risk of death and illness increases at this time, especially if the weaning process is abrupt. The amount of resources provided to some workers might have exceeded their caloric needs, even under conditions of hard labor; and since there are few indications that they received oil or clothing - the two other traditional products disbursed to institutional workers in Mesopotamia-they may have been meeting other needs by exchanging the excess barley they received (Widell 2005: 396-99; Jursa 2015:358-9). Vegetables, proteins, and dairy would have been among the items purchased, and the risk of infection from foods bought on the open market was great. Dairy is an amply attested commodity in Mesopotamia. The unpasteurized milk of the ancient world would have been dangerous for infants to consume, and the feeding of such products to small children has been characterized as "tantamount to manslaughter" (Parkin 2013: 53). ${ }^{37}$ It has been shown that using animal milk to feed young children in one early industrial group brought a sevenfold increase in child mortality, or 682 deaths per 1000 births (Hogan and Kertzer 1986: 368 ).

It seems that there is a body of comparative and cuneiform evidence to support an age of weaning for this population as late as the fourth year of life. The ages provided by our application of MLTs are at the far end of the attested age range for humans but are not without precedent. There is also some wiggle room in these results because the growth trajectory of this group is unclear and the methodology produces only coarse results. But even with these factors, one should still be cautious in accepting a nursing age range approaching five years even if it has been both observed for population under extreme environmental conditions and estimated from actual cuneiform tablets.

Adulthood and Age at First Marriage

In the data set all men who are known to be married are either in the adult category or their category is unknown. Except for a few atypical situations, the same is true for women (Tenney 2011a: 74 n. 45). The transition point for males

37 As far as I am aware, the archaeological record has not turned up any evidence that Babylonian families fed children animal milk via bottles. Supposed ceramic bottles have been found in Egypt and the Classical World (Dupras, Schwarcz, and Fairgrieve 2001: 205; Parkin 2013: 53; Fildes 1986: 10). 
and females from the category of adolescent to that of adult could be related to the age at which marriage was first acceptable, and the point at which this change occurs could serve as a stand-in for the important calculation of average age at first marriage (AAFM). If this is the case, then our workers on average entered marriageable age or were majority married at just over 23 for males and a little younger for females. The range of AAFM for women is the same regardless of which data are applied to the female table. AAFM is an important measure because it marks the point when women on average begin regular sexual relations and is a reference point for population stability and/or growth. Other measures of importance are birth intervals and the length of a woman's childbearing years (a factor of mortality).

Martha Roth used data from Neo-Babylonian legal texts and the Harran "census" to provide the first statistical and non-anecdotal approximation of AAFM for men, albeit while admitting that this was just an educated guess. She also posited that the Mesopotamians she studied practiced a Mediterranean marriage pattern, which sees a very large age gap between brides and grooms (Roth 1987: 747). She estimated the gap to be ten years, setting an AAFM for women in the middle to late teens. Some years later, Erlend Gehlken tracked the number of years in which 255 male scribes, smiths, and textile workers were mentioned in late Babylonian documents from Uruk and Sippar and conclusively argued that twenty percent of Babylonian men in his sample reached the age of 45 and that age at first marriage for men was around 20 (Gehlken 2005: 102) $\cdot{ }^{38} \mathrm{He}$ also assumed that women were younger than the men they married, and was adamant that Roth's estimate for women was too low. While the evidence and methodology of Gehlken's conclusions are more convincing than those of Roth, we must remember that both scholars were calculating AAFM for men which has marginal bearing on population change or stability. In both cases, the critical measure of female AAFM was based on assumptions about large age gaps between brides and grooms. ${ }^{39}$

Looking beyond these studies, one finds that there is a common pattern of nuptuality across all complex societies, with perhaps an exception of northwestern Europe (Hajnal 1965:101; Skinner 1997: 61-2). AAFM in the pre-industrial world almost universally rests at twenty years old or later regardless of time or region. There are exceptions, notably among very high-status families where

38 It has also been remarked that Assyrian princes in the seventh century вСE were in their twenties at first marriage, but this is mostly a presumption with little expressed backing evidence (Parpola 1983: 231 n. 390).

39 AAFM is also important in men, because older men will create more miscarriages (Hin 2013: 175). 
marriage was connected to extensive inheritances or in instances of delayed spousal coresidence (Coale 1971: 193-196; Hin 2013: 176; Lundh 2014: 97; Hajnal 1965: 101; Hanley 1974: 134; Hendrickx 2005: 76, 78; Viazzo 2005: 146; Saito 2005: 171; Plakans 1984: 262; Hoch 1982: 230). ${ }^{40}$ This does not mean that all women were married by twenty, and in all places where such data are available it is clear that some married earlier, later, or not at all. Even in parts of the contemporary developing world, one third of girls are married before the age of eighteen, mostly in West Africa and South Asia, but AAFM for these regions is still around twenty. ${ }^{41}$ The average AAFM for women in Rome and Roman Egypt was in the late teens or early twenties, which echoes our results for the test population. There was also variation between urban and rural practice (Hin 2013: 178). In neo- or virilocal households like those experienced by most urban Babylonians (Postgate 1994a: 92; Baker 2014: 6), AAFM tends to be inversely related to economic conditions. Men with fewer resources marry later on average. It is also an important determinant in spousal age gaps (Hin 2013:175), and our calculation points to small gaps among the test population. Literary sources claim that AAFM for wealthy Romans was in the mid-teens for women and in the late teens and early 20 for men, but these are statements of ideal practice and unlikely to be the population norm. Even if they were true, early AAFM for women was practiced by a very small and statistically insignificant portion of the Roman populace (ibid. 175-6). Future studies of AAFM in Babylonia, especially if drawn from texts involving extensive property exchanges, may likewise reflect the minority situation of marriage among people of means (see sections 10 and 14).

\section{$7 \quad$ Birth-Spacing and Family Size}

In the past, household health and size were determined by powerful biological forces. Large families risked the health of mothers in repeated childbirth, reduced maternal attention for children, and increased the financial burden on the entire family. These factors were especially acute for low-earning

40 In the year 2000, the United Nations determined that the average age in developed countries was 27.9 for males and 25.2 for females, compared to 24.9 and 21.4 in less developed countries. Afghanistan has some of the earliest marriage rates in the world and AAFM for women is still 18. (http://www.un.org/esa/population/publications/worldmarriage/ worldmarriage20ooPressRelease.htm).

41 International Center for Research on Women (http://www.icrw.org/child-marriage -facts-and-figures). 
households (van Bavel 2004: 96). Parents could use abstention, withdrawal, birth-spacing, or infanticide to control family size; but because death was unpredictable, families had little chance of raising a pre-determined, ideal number of children to adulthood (optimal family size). Extended periods of breastfeeding delay impregnation by an average of 1.7 years, and up to 4 years in extreme environmental conditions (Short 1984: 36 ). ${ }^{42}$ Sumerian and Akkadian proverbs warn that intercourse will spoil a woman's milk (Stol 2000: 184-5), so social practices may have extended parental celibacy. The available data on pre-modern families point towards an average size of conjugal families of 3-5 people (Burch 1967:353). This seems to apply for Mesopotamia and other parts of the ancient Near East, despite laws and practices that could have led to large families, e.g., polygyny, concubinage, slavery, no medical form of birth control, and strong familial ties (Bridges 1981: 36 ). Multi-generational families would be short-lived because of high mortality, and only half of children who reached age ten would still have a living grandparent (Levy 1965: 50; Hin 2013: 193). The average size of conjugal family units in the test population was 4.2, and a delay in complete weaning may have been one reason for its small size (Hin 2013:196; van Bavel 2004: 96). They were also majority nuclear, which is characteristic of societies with high mortality and as we will see, partible inheritance.

\section{8}

\section{The Elderly}

Because the number of elderly in our sample is small, our method set old age somewhere in the eighth decade. Other Mesopotamian sources set a similar age range for old age at least as an abstract concept. An aspirational literary text claims that 70 years of age represented a long life and that old age is equivalent to eighty years (Roth 1987: 717) ${ }^{43}$ Medical diagnoses were developed specifically for men over the age of seventy (Scurlock and Andersen 2005: 24). A number of Babylonians are attested as having lived into their seventies, and several rulers sat on the throne for fifty to sixty years, and plenty ruled for at least thirty years.

\footnotetext{
42 Biggs mentions plants and charms that Babylonians believed had contraceptive effects. Cf. his comments on birth spacing (2000: $5,8-10)$.

43 Compare the declaration in the source text (STT 400) "70 UD.MEŠ Gíd.DA.MEš [8]o ši-butú" with the sex-age designation for the elderly, šU.GI (š̃̌bu).
} 
Labor availability may have also been affected by the transfer of wealth through families via inheritance. Unfortunately, its effects on the entire Babylonian population cannot be quantified from cuneiform sources, and wealth for the test population cannot be determined beyond the payments in barley given to each worker. However, comparative evidence provides some important points concerning labor availability and population movement that Assyriologists should be aware of as they reconstruct social behaviors and search for better data in the cuneiform record.

To varying degrees, Babylonians used partible inheritance-the practice of dividing the estate of the departed among multiple heirs, usually sons or brothers (Westbrook 2003: 57-8). Since inheritance is one of the ways that social systems reproduce and structure interpersonal relationships, we find that partible inheritance also has a strong effect on residence patterns and household makeup. First, it is usually associated with simple family households and shortlived multiple-family households, because each child marries and establishes a residence (Berkner 1976: 71-2; Huebner 2013: 50-2). Second, it seems that in some regions partible inheritance led to dense populations in residential areas and encouraged males to stay close to their familial center (Goody 1976: 4; Hallam 1958: 341$).{ }^{44}$ It therefore constrained the mobility of free workers and made them less responsive to low wages. It would be especially true when parents had few adult male children and heirs. Demographic factors indicate that one-fifth of all conjugal families in the ancient world were childless and a further twenty percent had only daughters, which meant that as many as forty percent of all Babylonian couples had no male heir (Huebner 2013: 53). Almost seven percent of the conjugal families in the test population had no children at the time of recording, but we cannot track most of them to determine if they eventually became parents (Tenney 2011a: 85). Partible inheritance is a flexible system that leaves open a variety of strategies as heirs establish their own households and pursue economic opportunities made possible with their shares. One can see these maneuvers play out in Babylonian real estate and inheritance transfer documents (Berkner 1976: 72; Westbrook 2003: 58; Baker 2015: 376). Impartible inheritance leaves the entirety of the estate to a single heir, which encouraged the stem-family, a household form where a son (the heir) remains in the home of his parents after marriage. Those sons without a share lack opportunities and capital, and often become wage laborers, soldiers,

44 The low-density figures in Wilkinson (1999) would not argue against this since his calculations included entire regions: residential, farmland, swamps-i.e., settled and unsettled areas. 
vagabonds, and émigrés (Berkner 1976: 80; Hallam 1958: 361). Our data show majority nuclear households among servile groups, which correlates well with how we think the inheritance system would have affected household and residence. Extended families also appear, but never stem families with the father still alive (Tenney 2011a: 80).

About forty percent of the records contain additional information on allocations of grain to servile workers. These payments are scalar and based on sexage categories. There is also variety within many categories, and future work will undoubtedly reveal explanations for all of this internal variability. At present, it looks as if some of it is related to occupation, proximity to certain institutions, and the personnel designations amìlütu and tenēštu. Another cause could be measurement standards.

\section{Re-evaluating Measurement Standards}

In Late Bronze Age Babylonia, the base amount employed to measure grain, the measurement standard, is itself not standardized. The formula for expressing these standards is ŠE GIŠ.BÁN X sì LA, where X sets the measurement standard ("barley, (measured by) the $\mathrm{X}$-sìla sūtu"). If $\mathrm{X}$ is 5 , it indicates that approximately five liters of barley are the equivalent of the next highest measurement, the BÁN. If the standard is 10, it means that each BÁN is twice as large. The BÁN is the principal measurement for expressing monthly allocations to personnel, and the measurement standard (how many liters make up a BÁN) is critical to reconstructing worker income and system-wide costs.

Measurement standards tend to be written at the top of the tablet near the left corner. This is the most fragile part of the tablet, and as a consequence it is often broken off or destroyed. Texts may also include multiple measurement standards expressed throughout the document. For these reasons, few records of the test population have preserved standards or a single default standard. Outside of a handful of noteworthy texts, most of the records make it impossible to convert the total amount into a standard Babylonian unit with confidence. By extension, conversions into modern equivalents like the liter are unwise. Allocations to servile laborers were measured by at least three different measurement standards, the 5 -sì LA sūtu, the 10-Sì LA sūtu, the "great" (GAL) sūtu, 45 and perhaps the 6-sìlA sütu. Because standards are rarely preserved, the potential number of measurement standards in use could have been greater. In a 
satellite of Nippur, the 10-Sì LA sūtu and great sūtu are generally the measurement standards of choice in calculating agricultural yields, and the 5 -Sì IA sütu is commonly used for payments to individuals. ${ }^{46}$

Figure 8 is a table converting select quantities and their equivalent totals measured in sìla (roughly a liter) according to measurement standard. The time span of coverage (one month, two months, etc.) is unknown for most of these disbursals, but the period of one month may serve as a reasonable default.

\begin{tabular}{|c|c|c|c|c|c|}
\hline & $\begin{array}{l}12 \text { SìLA } \\
\text { (GAL?) }\end{array}$ & $\begin{array}{l}10 \text { SìlA } \\
\text { (GAL?) }\end{array}$ & 6 SìLA & 5 SÌLA & Select Attested Designations ${ }^{a}$ \\
\hline 1 SÌLA & 1 & 1 & 1 & 1 & DG \\
\hline 1 BÁN & 12 & 10 & 6 & 5 & DG, DSG \\
\hline 2 BÁN & 24 & 20 & 12 & 10 & DG, S, ST, STT, DSG \\
\hline 3 BÁN & 36 & 30 & 18 & 15 & G, GT, GTT, DG, S, ST, STT?, DSG? \\
\hline 4 BÁN & 48 & 40 & 24 & 20 & $\mathrm{G}, \mathrm{GT}, \mathrm{GTT}, \mathrm{S}, \mathrm{ST}$ \\
\hline 5 BÁN & 60 & $5^{0}$ & 30 & 25 & $\mathrm{G}, \mathrm{GT}, \mathrm{S}, \mathrm{ST}$ \\
\hline $1 \mathrm{PI}$ & 72 & 60 & 36 & 30 & G, GT, GTT, \\
\hline 1 PI 1 BÁN & 84 & 70 & 42 & 35 & \\
\hline 1 PI 2 BÁN & 96 & 80 & 48 & 40 & $\mathrm{G}, \mathrm{S}$ \\
\hline 1 PI 3 BÁN & 108 & 90 & 54 & 45 & \\
\hline 1 PI 4 BÁN & 120 & 100 & 60 & $5^{0}$ & $\mathrm{G}, \mathrm{GT}$ \\
\hline 1 PI 5 BÁN & 132 & 110 & 66 & 55 & \\
\hline $2 \mathrm{PI}$ & 144 & 120 & 72 & $6 o$ & G \\
\hline 2 PI 1 BÁN & 156 & 130 & 78 & 65 & \\
\hline 2 PI 2 BÁN & 168 & 140 & 84 & 70 & \\
\hline 1 GUR & 360 & 300 & 180 & $15^{\circ}$ & \\
\hline 2 GUR & 720 & 600 & 360 & 300 & \\
\hline
\end{tabular}

a DG=DUMU.GABA, DSG=DUMU.SAL.GABA, GTT=GURUŠ.TUR.TUR, GT=GURUŠ.TUR, G=GURUŠ, STT=SAL.TUR.TUR, ST=SAL.TUR, S=SAL. Texts in Istanbul were not available (Tenney 2011a: 38 )

FIGURE 8 Comparison of capacity equivalents by measurement standard (in SìLA/c. liters).

46 Ibid. A working hypothesis might be that measurement standard may be somewhat related to recipient: larger measurements for payments to the state as taxes, a smaller measurement for payments to individuals. 
There is a noteworthy pattern. Adult males are attested with seven different monthly allotments: 2 PI, 1 PI 4 BÁN, 1 PI 2 BÁN, 1 PI, 5 BÁN, 4 BÁN, and even as low as 3 BÁN. Four of these, including the three most common could all be equal total amounts: 2 PI measured by 5 SìlA standard, 1 PI 4 BÁN measured by 6 sìlA standard, 1 PI measured by 10 sì LA standard (GAL?), and 5 BÁN measured by the 12 sìla standard (GAL?). All of these equal a monthly total of 60 liters of barley (Figure 8), which is the recognized standard of monthly payment from the previous millennium (Gelb 1965: 233). ${ }^{47}$ Disbursals from our time display greater variability, which is the case in later periods (Jursa 2015). Some of the payments could be two-month payments of 60 liters per month as well (120 liters). This means that some of what appears to be a range of payment amounts could be an effect of the measuring system rather than different levels of compensation. Similar phenomena can be observed in some of the other sex-age categories. The degree to which measurement standards affect total amounts might be calculated in the future, but at present is unknown. There is variation in allocations within texts, i.e., 1 PI 4 BÁN and 1 PI are attested for adult males together, so all of the differences cannot be due solely to measurement standards. Any attempt to apply a blanket standard would be a distorting overgeneralization that may seem to work in select data sets. The sexigesimal counting system also has recurring multiples that would occur repeatedly in a random sample anyway.

\section{Individual cost}

Despite this minimum, monthly and annual payment totals per worker in each category can still be calculated to arrive at an estimate of minimum average cost per worker. ${ }^{48}$ We chose the mean attested monthly allotment (outliers are few for most categories) and the smallest, attested measurement standard (5 SìLA) to achieve a minimum possible cost (Figure 8). This reduces-if not eliminates - any "noise" caused by measurement standard uncertainty. Costs could only be greater than the figures presented here. Payments to the elderly are not attested, and they are omitted from the table.

47 On the basis of nine tablets from the 22nd and 21st centuries BCE, Gelb proposed that the average daily barley ration amount given to men and women was 2 and 1 liters, respectively. Waetzoldt connected age ranges and food allotments to a few workers in the Ur III period: ages $1-5=10$ liters, children $5-10=15$ liters, adult women $=30-40$ liters, and adult men $=60$ liters (See comments in second paragraph of section 6).

48 Here we also note that the data are not always uniform. Pirsu/pirsatu is not attested in most of the texts allocating grain payments. Instead, the statistics are based on the designation SAL.TUR.TUR. 


\begin{tabular}{llclc} 
& \multicolumn{2}{c}{ Males } & \multicolumn{2}{c}{ Females } \\
& monthly & annually & monthly & Annually \\
\hline Nursing & 10 & 120 & 10 & 120 \\
Weaned/Children & 15 & 180 & 15 & 180 \\
Adolescents & 25 & 300 & 15 & 180 \\
Adults & 30 & 360 & 25 & 300
\end{tabular}

FIGURE 9 Mean allocations for individuals in liters.

Given what has been established for age ranges and other data, Middle Babylonian servile children are compensated at similar minimum levels to about 10-11 years old. Modern recommendations follow a similar principle (Figure 10). At older ages, salary amounts increase in favor of males. The amount for adult males is fifty percent lower than what has been identified as the standard amount given for disbursals to adult males in the third millennium, but we have consciously selected a minimum payment amount from among a range of possibilities. It is irrelevant for our purposes, but pertinent if one is calculating nutritional value and wealth. Most categories are not heavily affected by this decision because there is less variety in paid amounts.

Since these payments were made to servile people whose ability to trade their labor on the open market was perhaps circumscribed, how does one account for governmental compensation policies that favor males? It cannot be related to men's role as breadwinner, because there was no generic family allotment, and children and married women were compensated individually even if combined into a single total amount for the household. Women received essentially the same payments regardless of whether their husband was alive and they were childless or if they were single mothers. ${ }^{49}$ It could have been related to the greater caloric needs of men and their presumed greater work capacity, or to an incentive of some kind. However, some women produced valuable trade goods - textiles in particular-and there is no observable favor demonstrated to them. Adolescent girls, those who tend to be missing, are compensated the least in comparative perspective. For adult men, our decision to choose a very low estimate results in a daily caloric intake that is just below

49 Sometimes the record combines payments to all family members into a single total based on the composition of the family, but there was no base "family" or "head of household" allotment. 


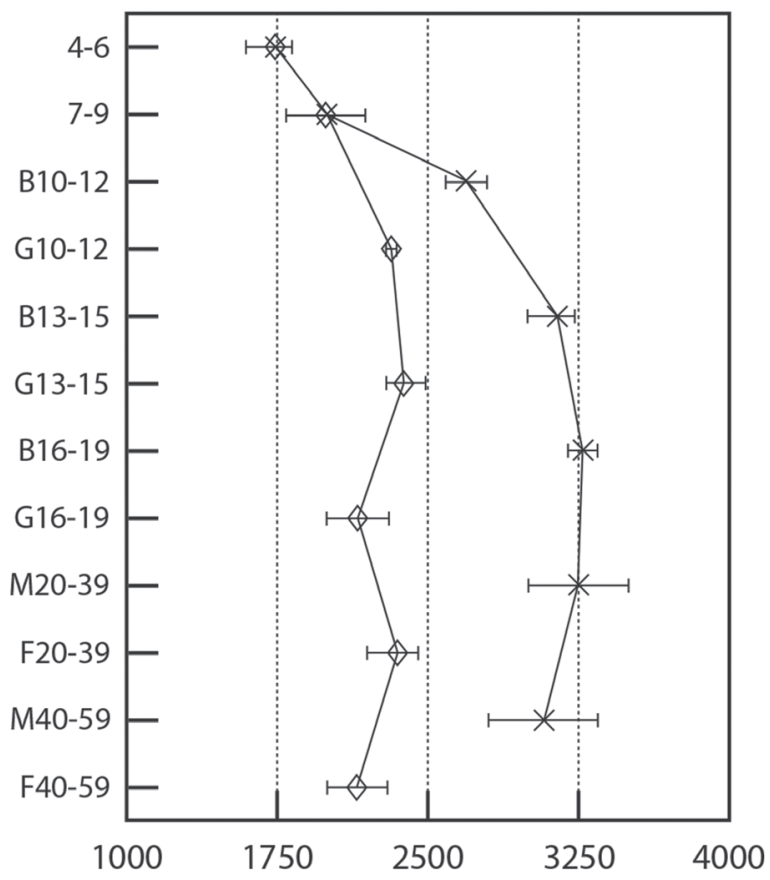

$\mathrm{G}=\mathrm{Girl}, \mathrm{B}=$ Boy, $\mathrm{M}=$ Adult male, $\mathrm{F}=$ Adult female

FIGURE 10 Ranges of daily caloric intake recommended by governmental bodies (Gallant 1991: 63, redrawn by the author).

modern recommendations for maintaining a stable weight (Widell 2005: 397; Paulette 2013: 105), but generic calculations like this are uncertain and have been criticized (Scheidel 2007: 61). ${ }^{50}$

\section{Payments as an Incentive to Increase Population Size}

Families were an important means of organizing and distributing food (Tenney 2011b: 143-4), but were the payments allocated to nursing children (who may not need solid food) a government incentive encouraging parents to conceive more children? These non-essential payments could be saved or spent until the child shifted to solid foods. There are several points arguing against this. First, Babylonian governments were sure to have known that active encouragement

5o Consider the issue of caloric intake raised by the test case to those encountered by scholars analyzing payments to Middle Assyrian workers, specifically the šiluhlū, working on agricultural estates in Syria (Wiggermann 2000: 186-187; Salah 2014: 39). 
of population growth was impossible, and they had records in their possession proving this (Tenney 2011a:114-5). Infant and child mortality were too high to make such incentives viable, and people had little to no control over the size and composition of their families (van Bavel 2004: 104). Such a strategy may have had the reverse effect, because increasing the size of a household places wives and existing children at risk. Second, nursing children are not always allocated food payments. If there was a policy to encourage conception through payments, then allocations would always be made to nursing children, even when they were too young to eat solid food. We have also seen that the extended nursing pattern which was extant in all their roster records limited population growth, and that nursing children eventually move to a mixed diet of breast milk and solid foods. It would also require a great degree of government control, which cannot be determined since the workers are of uncertain social status and possibly of mixed origins (statue laborers, slaves, etc.).

\section{Lifetime and Total Cost}

Now that minimum monthly grain allotments for each month of a worker's life have been established, the minimum lifetime cost of individual workers can be estimated (Figure 11). We assume a lifespan of 35 years, because the calculation requires that each person reach adulthood. Our mortality estimates state that once past the age of five, a person was likely to make it to age forty. In his study of Neo-Babylonian craftsmen, Erlend Gehlken observed that most men reached the age of 45 (2005: 107).

When we use these minimum disbursal levels, a woman cost $21 \%$ less than a male over an equivalent lifetime. If we were to maximize payment amounts,

\begin{tabular}{lrr}
\hline & Females & Males \\
\hline nursinga & 414 & 462 \\
weaned/children & 1,483 & 1,514 \\
adolescents & 2,032 & 3,411 \\
adults & 3,600 & 4,093 \\
total to age 35 & 7,529 & 9,480 \\
\hline
\end{tabular}

a Presumably one could remove 6o liters from the total for each person because they may have not received payments before they could eat solid foods at six months of age. This was not done for our calculations.

FIGURE 11 Lifetime allocations per female or male to age 35 (Liters of Grain). 


\begin{tabular}{lll}
\hline & Females & Males \\
\hline nursing & $17 \cdot 9 \%=2,148$ & $12.1 \%=1,45^{2}$ \\
weaned/children & $05 \cdot 9 \%=1,062$ & $06.9 \%=1,242$ \\
adolescent & $16.7 \%=3,006$ & $21.5 \%=6,450$ \\
adult & $59 \cdot 5 \%=17,850$ & $59.0 \%=21,240$ \\
annual cost per 100 & $\mathbf{2 4 , 0 6 6}$ & $\mathbf{3 0 , 3 8 4}$ \\
\hline
\end{tabular}

FIGURE 12 Annual allocations per 100 males and females (Liters of Grain).

the discrepancy between adult men and women would be much greater because there is greater variety in the attested amounts for men.

The annual allocation costs for every 100 males and 100 females can be determined, which provides some understanding of the costs of supplying working groups (Figure 12). Given established assumptions, ${ }^{51}$ the complete cost to the province of Nippur for all males who were ever part of the servile system can be conservatively estimated at $36,156,720$ liters. The cost of all females was $20,629,460$ liters. When we combine the amounts for males and females, we reach a total, estimated cost of $56,786,180$ liters; the equivalent of 1,611,455 bushels or $74,274 \mathrm{yd}^{3}$. The amount was enough grain to fill 4,951 average-sized garbage dumpsters and nearly to fill the cargo hold of a one thousand-foot Great Lakes freighter; ${ }^{52}$ it would have filled the famous ss Edmund Fitzgerald $21 / 3$ times over. In terms of mass, it weighed 38,675 tons if paid in barley and 45,121 tons if paid in wheat. This estimate excludes any "missing" girls and is restricted to the records of a single province.

\section{Servility as Presented by the State}

Given this investment and the labor needs of the state and elites, it is no surprise that explanations for servility and the means by which it was enforced

\footnotetext{
51 These assumptions are that all individuals were born and raised in the system and lived to age 35, payments were given throughout the year, and the sex ratio was 108. A conservative total of 3814 males and 2740 females is then reasonable (total cost males $=9,480 \times$ $3814=36,156,720$ liters; total cost females $=7,529 \times 2740=20,629,460$ liters $)$. 
are found in Mesopotamian literature, legal codes, and other documents related to the royal figure. I am unaware of any intertextuality, in the strict sense of the word, between the bureaucratic records pertaining to the least fortunate and the more lofty products of the scribal art (Seri 2014); but it is possible that scribal education and exposure to greater the scribal milieu led to a general awareness of such themes among the literati. The close connections between scribes and the political authority are also well established. This is important because the Nieboer-Domar hypothesis posits that servile systems can be made stronger through ideologies and laws that support servile systems and tie the central authority to regional elites.

Our examples of these explanatory narratives come from a variety of historical periods, but at least one of the Akkadian literary texts was composed a little over a century or even closer to the time of our test population (Tenney 2016). They demonstrate that servility in all of its manifestations was embraced and codified by the monarch or those writing on his behalf. In Atra-hasis, Enüma elišs, and The Toil of Babylon, classic Babylonian expositions on statehood that have a shared history, it is explained that the roles of mankind are to perform the work of the state and provide for the gods. The language in which these ideas are presented is specific to the lexicon of taxation and forced labor. Some of these same terms can likewise be found in administrative tablets (dullu), but there translated in a mundane and benign way ("work task", e.g., grinding grain).

Example 5. Atra-hasis. Old Babylonian version (Line numbers as in Foster, B. 2005: 229-77).

i 1-4. "When the gods were (like) men, they did forced labor (ublü dulla) ... the forced labor was heavy (dullum kabit), the misery too much ..."

i 240-41. Upon the creation of mankind, Mami addresses the formerly downtrodden gods with the following: "I have done away with your heavy forced labor (kabtam dullakunu), I have imposed your drudgery on man."

Example 6. The Toil of Babylon (Lambert 2013: 306-7).

i 5-8. "[The citizen of Babylon] was impressed (lit. "harnessed") into corvée (șamid ilku), [small and g] reat endured forced labor (dulla). [All of the citizens of Baby]lon were impressed into corvée, [small] and great endured forced labor." 
Example 7. Enūma Eliš tablet vi 33-34 (also 7-8, 35-36).

33-34. "From his blood, he (Ea) created mankind, on whom he imposed the forced labor (dullu) of the gods."

Note the language employed. Some of the words translated as "forced labor" or "corvée" encompass a range of meanings (dullu), or are not completely understood in all contexts and periods (ilku: e.g., Postgate 2007: 112, 2013: 21-2). Yet taken in their entirety and in light of the verbs used with them (șamādu, $e m \bar{e} d u$ ), it is clear that they are speaking of more than work in a general sense and that this labor originated with the state. The ideology advanced in these texts establishes working for institutions as a founding principle of political authority. Its performance was also recognized as onerous and undesirable and something that should be passed to individuals of lesser quality. In Atrahasis, dullu describes the tasks that the inferior Igigi gods were forced to perform for the seven Anunnaki gods, and the fulfillment of these obligations was transferred to mankind after their creation. By extension, one could argue that because these texts were allegories for an ideal Babylonia, the imposition of work on the less powerful was explicitly known to maintain the position of elites, whether they be gods or men.

Sumerian literature alludes to similar themes. The Eridu Genesis, another text opining on the nature of rule, states that the primary duty handed down to the ruler at the birth of government was to ensure construction. The work of the cities ([du]-lum-bi) required the establishment of names and the allotting of baskets, which in itself could be construed as a reference to basic state administration (Jacobsen 1987: 146; ETCSL t.1.7.4 segment B: 4-10). In the Gudea cylinder inscriptions, the ruler of Lagash orders the construction of a new temple to the god Ningirsu, and impresses his own people to do the work. Under normal conditions a harsh lash would have been used to motivate the residents of Lagash to clear the land and build the temple, but this was forbidden for this project. His motivations for this ban are unstated, but one could argue that it was done to maintain the ritual purity of the building site, rather than out of kindness for his subjects (Jacobsen 1987: 403-6). ${ }^{53}$ In both Enmerkar and the Lord of Aratta and Gilgamesh and Aka, one finds illustrations of violence

53 Steinkeller's view of this text is important because it differs from Jacobsen in both translation and tone, interpreting this as more of a festive event (2015: 149-50). His point is well taken and emphasizes the challenges of properly interpreting ancient documents that are written to glorify the state. 
connected with the imposition and maintenance of work service. In Enmerkar, the people of Aratta are subjugated and forced into state labor by violence or a contest that substitutes for violence. Failure to adequately fulfill one's duties was considered rebellion and punishable by killing and war. The subdued are not paid for their work, but it is the duty of the state to feed them. The conqueror also hopes or declares that after the day's work is performed, the subjugated peoples of Aratta will submit peacefully and sleep (ibid.: 146, 275-86, 345-55). Gilgamesh and Aka speaks to the other side, because it is a tale about how one subjugated group rebels against the labor that has been imposed on them by outsiders. And while I hesitate to reach too far, it is worth noting that the men who sally forth and face the enemy are the courageous subordinates of the men who instigate the conflict. These champions are called árad (slaves?) by Aka (ibid.: 351, 353).

Rulers used their legal authority to embed the ideal social order into the legal fabric of society. The prologue of the Laws of Lipit-Ištar establishes annual and monthly work obligations on adult males (Roth 1997, 25-6). These work assignments, whether considered forced servitude or a tax, are attested in other periods of Babylonian history by the references to the granting of freedoms from such obligations (Brinkman 1963: 239-40, 1974: 415). Legal codes also make it clear that criminal offenders could be punished with state servitude, even if their offense was not work-related (Example 10). Monarchs even penetrated into the private realm, and established that workers who failed to live up to their obligations to employers were considered to have committed a crime, and the ninth law of Eshnunna establishes a severe financial punishment if a person fails to show up for work (Roth $1987: 60$ ). ${ }^{54}$

Legal codes used punishments and incentives to place the responsibility of controlling the slave population on the local community, rather than the government. It was the duty of everyday people to catch runaway slaves (Example 8$)^{55}$ and to ensure that slaves did not engage in trade, acquire capital, or financial independence (a means to escape?) (Example 9). Commoners were also tasked with enforcing the distinct dress codes or identifying marks of slaves so that slaves were never mistaken as free people (Example 10).

54 In the West until the 19th century, absent workers were considered to have committed a crime against their employers. Benjamin Franklin was himself a fugitive from justice because he abandoned his apprenticeship to his brother (Eltis and Engermann 2011: 3). Similar expectations were integrated into the American Fugitive Slave Act of 1850, where all citizens were required to assist in the capture of runaway slaves. 
Examples 8-10. Legal Passages Concerning Community Control of Slaves and Labor Punishments.

"If a man seizes a fugitive slave or slave woman in the countryside and leads him back to his house, the slave owner shall give him two shekels of silver," с. 1750 ВСЕ.

"A merchant or a woman innkeeper will not accept silver, grain, wool, oil, or anything else from a male or female slave," c. 1770 BCE.

"Slave women shall not be veiled ... If a man should see a veiled slave woman but release her and not seize her, and does not bring her to the palace entrance ... they shall strike him 50 blows with rods; they shall pierce his ears, thread them on a cord, tie it at his back; the one who informs against him shall take his garments; he shall do the king's service for one full month," c. 1100 B CE.

IBID.: $61,84,168-9$

Kings throughout the Near East set similar responsibilities on their political neighbors. Provisions found in treaties guaranteed the extradition and curbed the granting of asylum to fugitives who fled to foreign lands (Brinkman 1990: 96; Liverani 1987: 69; Van De Mieroop 2007: 148). These people may have been elite political refugees; but in Late Bronze Age Babylonia, the primary word for "fugitive", munnabittu, was applied to servile people (Tenney 2011a: 123, 128-9; Foster 2010: 47-48). For all of the above reasons, one might therefore question the extent to which early states could or chose to project power into the many small communities under their purview (Adams 2007). Debts and rents may have also been a means of binding laborers to elites on a local level.

It has been written that Babylonia and Sumer had only a small percentage of slaves at any given time. This is repeated often and used to contrast Mesopotamia with the archetype of ancient slave societies, Rome (Gelb 1980: 35; Stol 1995a: 136; Adams 2007: 1). This statement is specific to chattel slavery, but it is worth revisiting because it is common in the literature and has wide implications for all types of servility (if one chooses to separate them) in the broader sense and measurements of Mesopotamian subpopulations in general. 
The statement could be true because the cost of slave ownership must have been restricted to only the most prosperous members of society (Scheidel 2005). However, we cannot substantiate the claim with certainty because Mesopotamian population studies are in a primitive state, especially with measures below the level of settlement proxy data. At a minimum, to my mind statements like this must be supported by an observable fraction or percentage, e.g., $1 / 3$ or $33.3 \%$. The numerator would be the total number in the subpopulation and the denominator would be the entire population of Babylonia (or the city/region of concern). At present, there is no reliable and certain way to determine either of these measures. Using slaves as an illustration, one would first have to negotiate the definitional quagmire of "slave," and decide upon the terms or characteristics that would qualify a person for the data set. The pitfalls of this approach were already covered in the introduction. Even if such parameters are set, one would still have to possess a total for the number of slaves in the study region, and such certainty is not attainable in all but a few exceptional cases, none of which are in Babylonia. It is impossible to be sure if all slaves were recorded or if all pertinent documentation was recovered. The same would be true of any other subpopulation, like foreigners or pastoralists. The only exception to this would be estimates of males and females in most age groups, which can be determined through MLTs.

The other part of the calculation, the denominator, is an even more distant objective. To date, the basic tool of population research in Babylonia and Mesopotamia is the aforementioned surveys of settled, urban areas. The assumption of pottery surveys is that sherd scatter or landscape features correspond directly to population and therefore survey data can serve as proxy data on populations. The scholars who work with this material in depth have noted several shortcomings of this assumption, and some archaeologists have developed ways to mitigate any negative effects (Wilkinson 1999). As applied to the region of discussion here, one problem is that important areas of Babylonia have not been surveyed or the surveys have yet to be published. This includes the Tigris watershed and the marsh region of the deep south, areas which grow in importance beginning in the mid-second millennium. Second, the diagnostics of settlement surveys are coarse and centuries of pottery production are undetectable (Brinkman 1984b: 170-2, 175). Third and fourth, the exact relationship between surface survey and inhabited region is unknown, as is the density of occupation within a residential area (Postgate 1994b: 51; Wilkinson 1999: 45-7). Lastly, there is no consensus about average household size (Netting 1982: 641). The last three issues may have also been subject to regional variation.

Progress is being made in almost all of these areas. The Sealand region of far southern Iraq has now been partially surveyed, and pottery diagnostics 
have been further refined (Armstrong and Gasche 2014). Maps and surveys of nineteenth-century Aleppo have been combined with some residential exposures in the Near East to get some sense of house density (Schloen 2001: 12930), although Aleppo may have already been feeling the effects of the great demographic transition when the source material was compiled. Noteworthy estimates for regional denominators or population densities have been made based on certain assumptions (Yoffee 2004: 43; Wilkinson 1999: 53), but are usually proposed as a range of estimates that are unfortunately too broad and statistically imprecise for the topics at hand (cf. ibid: 46-8). Evidence accumulated from cuneiform texts points to an average conjugal family unit size of 3-5 people and a majority household situation of the simple, nuclear type (Tenney 2011a: 77, 82; Gehlken 2005: 105; Baker 2014: 14; Bridges 1981: 31; Desrochers 1978: 355; Roth 1987: 736-7; Vidal 2014: 47). These matters are not settled, and arguments for larger conjugal families and more frequent complex households have been published (Schloen 2001: 126; Stone 1981: 29; Diakonoff 1985: 65; Widell et al. 2013: 112; McClellan 1997: 45-6; Stol 2000: 180). Most of the evidence on household comes from settled, urban, and low-status social contexts; and an expanded data set of households, especially in previously unstudied regions, may lead to reassessments. One anticipates more household complexity in rural areas, but really large households often require state policies and incentives that encourage their formation and persistence (Kertzer 1991: 157-8; Huebner 2013: 52-3; Hoch 1982: 230, 240-1; Engelen and Wolf 2005: 23). There is no evidence of similar incentives in Babylonia. Discussions of families and households are made more complicated by fact that familial terms, especially the word "household" itself, are used inconsistently by ancient Near Eastern scholars and rarely as defined by historical demographers (contrast Foster, C. and Parker 2012: 3-5; Laslett 1974: 28-31; Tenney in press; Baker 2014 and 2015; Schloen 2001; Ur 2014). Without a unified terminology, comparisons and common points of agreement will continue to elude us.

\section{Conclusion}

Servility was endemic in Babylonian society and a crucial part of state identity and expression. It can be observed directly and indirectly in the Babylonian cuneiform record, and Assyriologists have used this record to divide servile peoples into distinct categories, setting each within their documentary context. As an aggregate phenomenon, servile systems were a well-established strategy of ensuring a consistent source of labor with fixed costs in a demographic situation with limited available labor. 


\section{The Nieboer-Domar Hypothesis}

As we saw above, the Nieboer-Domar hypothesis proposes that large-scale institutional servitude develops in regions with abundant, free land that is open for settlement. It also requires that the population levels be low relative to this undeveloped land. In such a situation, one cannot have this free land, free workers willing to work for wages, and a non-working land-owning class operating in a primary agricultural economy (Nieboer 1900: 308; Domar 1970: 2). Two additional elements that affect these three factors are government measures and political forces (Domar 1970: 21). As potential workers appropriate their own land or employment in open territory, the aristocracy will have to turn to wage labor to cultivate their estates or perform major projects. Workers who are free to move can create competition among landowners and drive up wages to the point where there is little profit or surplus. In response, the government or other institutions will instigate policies to restrict the movements of these workers or create social and legal structures to bind them to landowners and institutions. The means of implementation-rents, slavery, serfdom, institutional dependents, etc. - thus have the same function and can affect the lives of servile workers in similar ways. Once imposed, competition for labor will cease and the landowners can enhance their own profit, primarily by reducing the payments to workers to subsistence levels. The status of the non-working agricultural owners and institutions may be propped up further through taxation privileges; these policies will be even more ingrained if the government controls and distributes land (Domar 1970: 20).

Most of these requisite factors were present in Babylonia, at least periodically. Surveys have revealed significant oscillations in settlement, which would have led to a small population relative to land. In addition, settlement surveys and documentary evidence have demonstrated that land in Babylonia was probably not fully developed through most of its history, and this development required local and regional political and economic investment to build and maintain an irrigation infrastructure (Adams 1981: 143, 165; Postgate 1994a: 179). The need for "national"-level capital investment seems to have increased in the mid-second millennium. It is likewise clear that Babylonian states were involved in the allocation of land, even if there is some disagreement about the extent of government land control (ibid.: 183). Mesopotamian states even provided servile laborers to elites and to temples (Gelb 1972: 85).

Given the well-established scholarship on Babylonian settlement and land use, this paper has focused on the other requirement of the Nieboer-Domar hypothesis, persistently low population levels. It has argued that labor availability in Babylonia was a byproduct of shifting populations, demographic pressures, and family institutions. It has also suggested that Babylonian popu- 
lations may have experienced almost imperceptible population growth over the long term, and that regions experiencing traumatic events leading to high mortality or significant emigration, would have found it challenging to stabilize or even grow in the years following such events. As a consequence, we see that internal and external population movements were the most important factors in the growth of Babylonia and its subregions. ${ }^{56}$ Birth would have brought stability; but growth through births alone would have been slow, barely perceptible, and undependable. ${ }^{57}$ The divide between land and labor would have been especially large after some of the more dramatic periods of population stress when urban regions were repopulating or new lands became available after conquest. One could surmise that this would be a time when elites and institutions whose power may predate the new central authority would seek to consolidate their own positions, and the state would invest heavily in the needs of elites and in irrigation and farming infrastructure to improve taxable yields. In the case of drastic reductions or consistent decline, recovery would be slow and would not be able to respond to a rapid rise in labor demand. It has been argued that this was the case in the century leading up to the establishment of the test population. A new Babylonian dynasty in Babylon was rebuilding the agricultural and cultic infrastructure in Southern and Central Babylonia, which had supposedly been deurbanized or even depopulated for over a century (Adams 1981: 165-68, Bartelmus 2010: 167).

We have also explored the role that social factors delaying marriage, decreasing fertility, or restricting movement could have affected demographic growth and labor availability. Partible inheritance practice may have further reduced the number of men available to work menial jobs and made it less likely for them to move to areas in need. At present the evidence from the test population is weak, but comparative evidence suggests that those men who did migrate for work tended to be single and employed in unskilled labor or military work. The same socio-cultural factors may likewise have affected population dynamics by skewing sex ratios towards males in localities in need of workers (Hin 2013: 228-29). In the extreme event of forced migrations, one would

$5^{6}$ Gibson sees such shifts as contributing factors in the development of Mesopotamian complexity (1973).

57 An example of migration's importance was illustrated by a recurring problem of the M.A.s.s. project, whose virtual villages would evaporate with the passage of time. The problem was solved by inflating both the rate of population growth and the number of children born outside of non-legally sanctioned arrangements, i.e., from unwed mothers, rather than modifying assumptions about migration (Christiansen 2013: 90-92, 164; Altaweel 2013: 282). 
expect sex ratios that differ significantly from the normal source population, further suppressing fertility (Eltis and Engermann 1992, 1993; Harris 1999: 69).

Death and sickness were ever-present and if mortality conditions of other pre-modern societies apply to Babylonia, then any available workers would have been incapacitated for extensive periods, further limiting the labor pool. These same factors would have led to many destitute and vulnerable people whose only recourse may have been to enter into undesirable relationships with the state, elites, or institutions. The most conspicuous among them, widows, are amply attested in the records of servile systems. Similar sentiments have been identified in Atra-hasis, a Babylonian epic poem. It mentions the sale of children by starving parents and the limits that childbirth and early childhood mortality set on populations. This literary work has been characterized as an explanation of the Mesopotamian concept of population control (Kilmer 1972: 169), but one could also say that it was a commentary and rationalization of the biological forces Babylonians faced on a daily basis.

Some aspects of humanity exhibit great diversity—architecture, art, religion, thought. However, its basic foundations - family, marriage, householdhave little variation and humans seem to operate within a restricted range of possibilities, especially in the pre-modern world. With that in mind, one can advance simple explanations for extraordinary observations. Two examples presented in this paper are food payments to children who are nursing and a marked absence of girls in bureaucratic records. One might argue that families were actively encouraged to reproduce and that girls were being sold or given away as marketable commodities. Alternatively, the evidence may point to common human behaviors like extended, gradual weaning and common marriage practice.

Moving beyond the later second millennium, there may be other time periods where future scholars could test the Nieboer-Domar hypothesis. Research on the Persian period has demonstrated the economic strain placed on institutions when adequate forced labor is not available, and authorities turn to wage labor to meet the majority of its labor needs (Jursa 2014: 174-81; 2015: 359-61; Kleber 2012). Changes in valuation at this time dictated that compensation be made in silver rather than the agricultural products that were available to landcontrolling institutions, which made wage labor even more economically burdensome. This period also marks the beginning of a massive increase in both population and land use in Babylonia, and Domar claimed that once population expands past a certain threshold and overcomes the land/labor problem, servile systems will decrease (Domar 1970: 28). There could be important consequences if it can be demonstrated that the forced labor shortages of the Persian period were typical rather than rare occurrences. One could also consider the role that servility and population dynamics played in the increase 
of settlement in Assyria during the eighth and seventh century вСе, recently attributed almost entirely to deportations of conquered peoples (Ur et al. 2013: 9o). One of the noteworthy features of migrating families over large distances or into frontier-like situations is a short burst in fertility, and there exists some evidence that this may have happened to forced migrants in Assyria (Fales 2009-10: 177). Given the constraints placed on the population by infectious disease, one also wonders if efforts by governments to increase agricultural production on its own would have led to appreciable natural population growth. This may have significant repercussions for those scholars working on urban development in Mesopotamia, who often see a direct positive relationship between yields and fertility.

\section{Final Thoughts on Wealth, and Servility}

Since this paper deals with population dynamics among one particular group of bonded laborers, we should consider if some of the population pressures previously discussed might be exacerbated by their servile condition. In this regard, we must be careful to separate out mortality - the measure which formed our primary focus - from quality of life. Status and wealth were unlikely to affect the former, but they certainly helped with the latter (Roberts and Manchester 2005: 42, 165). We have noted that mortality, morbidity, and some social institutions were perhaps not appreciably distinct across social classes, and so one could argue that when we restrict our discussion to these factors, our work on servile people may be germane to most Babylonians. Caloric intake, which likely varied by wealth and status, is relevant to mortality only once epidemics are curbed; and in the absence of modern medicine this was not the case in Mesopotamia. In fact, illness was probably more of a limiter to an individual's well-being and mortality than hunger would have been (Hin 2013: 103, 107; Scheidel 2007: 35-6, 41, and 61-62). Geography would also have been much more important than wealth, but if wealth allowed people to live away from disease-prone areas, then it could have had an indirect role in mortality. Mortality was certainly higher in cities than in the countryside, and increasing urbanization could have caused a rising population deficit. Rome has been characterized as an urban graveyard, and perhaps the same was true of the great metropolises of Babylonia (Hin 2013: 210-2). Most importantly, we are unable to determine the percentage of the population that was servile. Until there is evidence to the contrary, one would expect that mortality for the test population was not that appreciably different from the population at large.

Further research will undoubtedly reveal a complex situation and numerous exceptions to what has been proposed here. Nearly all overarching explanations of social, economic, or political features over the very long sweep of 
Babylonian history cannot account for every event or social institution. In the introduction, I stated that the greatest determinant in analyzing servility is the criteria one uses to delineate servile people, which will always be a matter of personal judgment. Both the restrictive definitions enabled by the lexical approach and the more inclusive interpretation given here are defensible in my mind. Miguel Civil once wrote of Sumerian grammar that we should look for "regularities and patterns", and that explanations of phenomenon need not account for all instances of that phenomenon, nor are they necessarily invalidated by a counterexample (Civil 200o: 29). I would posit that the same may be true for reconstructions of past populations. Not all sources need to agree to establish a trend or to understand aggregate and typical behavior.

Even with fixed, calculable, labor costs that were not subject to market forces, servile systems may have strained Babylonian government resources during extended periods of low yields. Nippur allocated an estimated 57 million liters of grain to its servile population. This is a conservative estimate, and the figure may have been much greater. The province also paid salaries to many people who do not seem to be servile and fed tens of thousands of animals, and these costs have yet to be calculated. Work on the income stream of Kassite Nippur is in a preliminary stage, but there are indications of precipitous drops in taxable crop yields. Over several years, one region known to benefit from servile labor experienced a production decline of nearly $63 \%$, and presently available evidence suggests that during some years the taxes would not have been enough to feed a total of 200 servile men, women, and children. Some working groups were itinerant, a residential strategy that met the labor needs of the widespread regions of the province, but probably also spread the burden of feeding workers throughout a network of regional storage facilities. Likewise, workers and recaptured escapees were loaned out to individuals and institutions, who shared in the cost of their upkeep. This system of labor and cost sharing would give elites more reason to support the current regime, and the government would be able to retain control over a major resource without incurring some of its cost.

\section{Ideology}

Servile systems were exploited by the empires, kingdoms, city-states, cultic institutions, and the elites of Babylonia, and the idea of work was embedded in ruling ideologies. Elites and religious institutions could destabilize central governments, especially when they were consolidating power or were in a weakened state. It is therefore understandable that governments would bend resources to satisfy the elite agenda and extend these ideologies to enforce 
the interests of both parties and to maintain their position (Yoffee 2004: 38). Section eleven of this paper may underscore this point. It suggests that a servile system will persist even if it exceeds much of its economic utility because it maintains social structures.

The desire to reinforce the structures that made servility possible were embedded into specific passages of important literary works. These texts have lexical ambiguities, tone and meaning can be elusive, and interpretations may vary. However, if we look at them in the context of Mesopotamian literature as a whole - which very much exists in the political realm-it makes sense that these texts would be a vehicle in which these themes are expressed. Moreover, challenges to the social and political order are the rare exception in Mesopotamian literature. One can find many instances of extolling to young, junior, or subservient members of society the merits of performing designated tasks, following masters (even if foolish), and allowing male elders to make the important life decisions of junior family members. As examples, one could point to tales of master and teacher ("School Days" and "The Advice of a Supervisor to a Younger Scribe"), or the way in which Inana and Dumuzi play out their courtship within the boundaries established by their family heads in Sumerian songs and poems. Even the great hero Gilgamesh cannot escape this rule of the Babylonian mythological universe. The rebellion he leads against forced labor and the chains of oppression, celebrated in Gilgamesh and Aka, fails. In the aftermath he and his companions both affirm their allegiance and praise their political overlord—all thoughts of prior oppression forgotten.

\section{Addendum 1: Morbidity and Medical Texts}

Retrospective diagnoses of ancient words are given in italics and should be read with appropriate caution.

Example 11. Medical Diagnosis Concerning Diarrhea followed by Death (Late 2nd Millennium BCE).

[If a] 'person' is sick with a ' ${ }^{\ulcorner}$wasting ${ }^{\top}$ curse, whatever he eats does not rest easy in his stomach but he pours (it) raw into his anus ... he will die. SCURLOCK AND ANDERSEN 2005: 129

Example 12. Medical Diagnosis Concerning Diarrhea, perhaps Caused by Cholera (Late 2nd Millennium вСE). 
'If ${ }^{\urcorner}$when (a confused state) comes over him, his limbs waste away (and) his abdomen continually afflicts him (and) the bowels are continually loose, 'hand' of ghost.

IBID. 49

Example 13. Medical Diagnosis Concerning Enteric (Typhoid) Fever and Dysentery Caused by Infected (?) Food (Late 2nd Millennium вСE).

"[If] a 'person' eats bread (and) drinks beer and subsequently his stomach is colicky, he has 'cramps' (and) he has "flowing if the bowels," enteric (typhoid) fever has 'gotten' him"

IBID.: 52

Example 14. Incantation against Various Diseases including Dysentery (Early 2nd Millennium BCE)

Congestion, fever, dizziness, pox,

Falling sickness, stomach ache (?), redness,

Boils, rash, tender sores, putrid sores,

Itch, inflammation, bloody stools, dehydration ...

FOSTER, B. 2005: 177

Example 15. Incantation involving Intestinal Distress (Early 2nd Millennium BCE)

My flesh keeps (stabbing) like a dagger, goring like a bull

My face is clouded over, like a widow's

Like a wave, it wears away the banks,

It inflamed my intestines ...

IBID.: 185

Example 16-17. Diagnoses Concerning Transmission of Disease in the Home and through Direct Contact.

If persistent 'grabbing of the throat' continually afflicts him ...(and) he dies, afterwards his mother will die ... his brother will die.

If he gets up and (his) hand is grasped (by others), if that patient dies, there will be another patient after him. 
Example 18. Incantation Against Epidemics of Fever.

Fire, fire

Fire seized a lone man.

It seized (his) insides, (his) temple,

It spread (to others) the gnawing of his insides,

The stock of the human race was diminished

FOSTER, B. 2005: 971

\section{Addendum 2. Prior Measures of Mesopotamian Population Growth}

This paper has proposed a low rate of annual growth of the population. Previously, scholars of Mesopotamia interested in these matters turned to a calculation that set growth at 0.10 . This is the same estimate used to measure the growth of the entire population of the earth from the Neolithic Revolution until the Demographic Transition (Coale 1974). As far as I am aware, the origins of this measurement for the ancient Near East are based on two articles, one by Braidwood and Reed published in 1957, and the other by Carneiro and Hilse in 1966. The study by Braidwood and Reed was the first modern attempt to estimate the size of the Babylonian population. They proposed that the population of ancient Sumer was 340,00o because they believed that the region consisted of no more than twenty cities whose average population was 17,000. Upon the advice of colleagues, they increased their estimate to half a million. They were aware that they were proposing a guess based on a number of assumptions, declaring that their statistics "should not be quoted" (Braidwood and Reed 1957: 29). Nine years later, Carneiro and Hilse turned to this figure because they wanted to estimate the rate of population growth in the Near East. Carneiro and Hilse assumed (and they clearly label it an assumption) that in $8000 \mathrm{BC}$, the population of the entire Near East (Fertile Crescent, the Levant, Egypt, and the Arabian Peninsula) was 100,00o people. They felt that across this area, there were roughly 2000 settlements of 50 people or 1000 settlements of 100. The Braidwood and Reed figure provided them the second, necessary figure that they would need to calculate change. They doubled the Braidwood and Reid figure because they thought that Egypt and Mesopotamia must have had the same population and doubled this sum to encompass the rest of the Near East, arriving at a total population of 2 million. They then determined that the most likely rate of annual growth that would allow for the Near Eastern population to grow from 100,000 people in 8000 BC to 2 million people in $4000 \mathrm{BC}$ was between .08 and .12 percent. The average of these rates has become the 
primary figure quoted and used in most scholarship trying to estimate average Mesopotamian population growth (e.g., Hassan 1981; Wilkinson 1999).

\section{Bibliography}

Adams, Robert McC. 1981. Heartland of Cities: Surveys of Ancient Settlement and Land Use on the Central Floodplain of the Euphrates. Chicago: University of Chicago Press.

Adams, Robert McC. 2007. The Limits of State Power on the Mesopotamian Plain. Cuneiform Digital Library Bulletin 2007/1: 1-3.

Adams, Robert McC and Hans J. Nissen. 1972. The Uruk Countryside: The Natural Setting of Urban Societies. Chicago: University of Chicago Press.

Akin, John S. et al. 1986. Breastfeeding Patterns and Determinants in the Near East: an Analysis for Four Countries. Population Studies 40: 247-62.

Altaweel, Mark. 2013. Discussion and Conclusions. In Models of Mesopotamian Landscapes: How Small-Scale Processes Contributed to the Growth of Early Civilizations, eds. T.J. Wilkinson, M. Gibson, and M. Widell. BAR International Series 2013. Oxford: Archaeopress: 255-275.

Anastasiou, Evilena and Piers D. Mitchell. 2015. Human Intestinal Parasites and Dysentery in Africa and the Middle East Prior to 1500. In Sanitation, Latrines, and Intestinal Parasites in Past Populations, ed. Piers D. Mitchell. Surrey: Ashgate: 121-47.

Armstrong, J. A. and Gasche, H. 2014. Mesopotamian Pottery: A Guide to the Babylonian Tradition in the Second Millennium B.C. MHE T 2/4. Chicago: University of Ghent and Oriental Institute of the University of Chicago.

Ataç, Mehmet-Ali. 2010. The Mythology of Kingship in Neo-Assyrian Art. Cambridge: Cambridge University Press.

Bagnall, Roger S. and Bruce W. Frier. 1994. The Demography of Roman Egypt. Cambridge: Cambridge University Press.

Baker, Heather D. 2014. House Size and Household Structure: Quantitative Data in the Study of Babylonian Urban Living Conditions. In Documentary Sources in Ancient Near Eastern and Greco-Roman Economic History Methodology and Practice, eds. Heather D. Baker and Michael Jursa. Oxford: Oxbow Books: 7-23.

Baker, Heather D. 2015. Family Structure, Household Cycle, and the Social Use of Domestic Space in Urban Babylonia. In Household Studies in Complex Societies. Chicago: Oriental Institute of the University of Chicago: 371-407.

Barnett, R.D. 1960. Assyrian Palace Reliefs and Their Influence on the Sculptures of Babylonia and Assyria. London: Batchworth Press.

Bartash, Vitali. 2015. Children in Institutional Households of Late Uruk Period Mesopotamia. ZA 105: 131-38. 
Bartelmus, Alexa. 2010. Restoring the Past: A Historical Analysis of the Royal Temple Building Inscriptions from the Kassite Period. KASKAL 7:143-71.

Berkner, Lucy K. 1976. Inheritance, Land Tenure and Peasant Family Structure: A German Regional Comparison. In Family and Inheritance: Rural Society in Western Europe, 1200-180o eds. Jack Goody, Joan Thirsk, and E.P. Thompson. Cambridge: Cambridge University Press: 71-95.

Biggs, R.D. 200o. Conception, Contraception, and Abortion in Ancient Mesopotamia. In Wisdom, Gods, and Literature: Studies in Honour of W.G. Lambert, eds. A.R. George and I.L. Finkel. Winona Lake, Indiana: Eisenbrauns: 1-13.

Bloch, Yigal. 2008. The Order of Eponyms in the Reign of Shalmaneser I. Ugarit Forschungen 40: 143-78.

Börker-Klähn, Jutta. 1982. Altvorderasiatische Bildstelen und vergleichbare Felsreliefs, Tafeln. Mainz: Philipp von Zabern.

Braidwood, Robert J. and Charles A. Reed. 1957. The Achievement and Early Consequences of Food-Production: A Consideration of the Archaeological and Natural-Historical Evidence. In Population Studies: AnimalEcology and Demography. Cold Spring Harbor Symposia on Quantitative Biology 22. Cold Spring Harbor NY: Biological Laboratory: 19-31.

Bridges, Susan Jan. 1981. The Mesag Archive: A Study of Sargonic Society and Economy. Ph.D. diss: Yale University.

Brinkman, J.A. 1963. Provincial Administration in Babylonia under the Second Dynasty of Isin. JESHO 6: 233-42.

Brinkman, J.A. 1974. The Early Neo-Babylonian Monarchy. In Le palais et la royauté, ed. Paul Garelli. Paris: Paul Geuthner: 395-408.

Brinkman, J.A. 1980. Forced Laborers in the Middle Babylonian Period. Jcs 32: 17-22.

Brinkman, J.A. 1982. Sex, Age, and Physical Condition Designations for Servile Laborers in the Middle Babylonian Period. In Zikir Šumim: Assyriological Studies Presented to F. R. Kraus, eds. G. van Driel et al. Leiden: Nederlands Instituut voor het Nabije Oosten: $1-8$.

Brinkman, J.A. 1984a. Prelude to Empire: Babylonian Society and Politics, 747-626 B.C. Philadelphia: Babylonian Fund, University Museum.

Brinkman, J.A. 1984b. Settlement Surveys and Documentary Evidence: Regional Variation and Secular Trend in Mesopotamian Demography. JNE S 1984: 169-90.

Brinkman, J.A. 1990. Political Covenants, Treaties, and Loyalty Oaths in Babylonia and between Assyria and Babylonia. In I Trattati nel Mondo Antico: Forma, Ideologia, Funzione, eds. Luciano Canfora, Mario Liverani, and Carlo Zaccagnini. Rome: "L'Erma" di Bretschneider: 81-112.

Burch, Thomas K. 1967. The Size and Structure of Families: A Comparative Analysis of Census Data. American Sociological Review 32: 347-63.

Carneiro, Robert L. and Daisy F. Hilse. 1966. On Determining the Rate of Population Growth During the Neolithic. American Anthropologist 68: 177-80. 
Charpin, D., Edzard, D.O., and Stol, M. 2004. Mesopotamien: Die altbabylonische Zeit. ово 16o/4. Fribourg: Academic Press; Göttingen: Vandenhoeck und Ruprecht.

Christiansen, John H. 2013. The Modelling Framework. In Models of Mesopotamian Landscapes: How Small-Scale Processes Contributed to the Growth of Early Civilizations, eds. T.J. Wilkinson, M. Gibson, and M. Widell. BAR International Series 2013. Oxford: Archaeopress: 152-176.

Civil, Miguel. 2000. Sumerian Modal Prefixes. Acta Sumerologica 22: 29-42.

Clarysse, Willy and Dorothy J. Thompson. 2006. Counting the People in Hellenistic Egypt. Cambridge: Cambridge University Press.

Coale, Ansley J. 1971. Age Patterns of Marriage. Population Studies 25: 193-214.

Coale, Ansley J. and Paul Demeny. 1966. Regional Model Life Tables and Stable Populations. Princeton: Princeton University Press.

Cohen, Mark Nathan. 1989. Health and the Rise of Civilization. New Haven: Yale University Press.

Cooper, Jerrold. 1986. Presargonic Inscriptions. New Haven, Connecticut:The American Oriental Society.

Dahl, Jacob L. 2010. A Babylonian Gang of Potters: Reconstructing the Social Organization of Crafts Production in the Late Third Millennium BC Southern Mesopotamia. In City Administration in the Ancient Near East: Proceedings of the $53^{e}$ Rencontre Assyriologique Internationale 2, eds. L. Kogan et al. Winona Lake, Indiana: Eisenbrauns.

Dandamaev Muhammad A. 1984. Slavery in Babylonia. DeKalb: Northern Illinois University Press.

Desrochers, Michael John. 1978. Aspects of the Structure of Dilbat during the Old Babylonian Period. Ph.D. diss. University of California Los Angeles.

Detwyler, Katherine A. 1995. Breastfeeding: Biocultural Perspectives, eds. StuartMacadam, Patricia and Katherine A. Detwyler. New York: De Gruyter: 39-73.

Diakonoff, I.M. 1972. Socio-Economic Classes in Babylonia and the Babylonian Concept of Social Stratification. In Gesellschaftsklassen im Alten Zweistromland und in den angrenzenden Gebieten XVIII. Rencontre assyriologique internationale, München, 29. Juni bis 3. Juli 1970, ed. D.O. Edzard. Bayerische Akademie der Wissenschaften: Munich: 41-52.

Diakonoff, I.M. 1985. Extended Families in Old Babylonian Ur. ZA 75: 47-65.

Dittmann, Karola and Gisela Grupe. 200o. Biochemical and Paleopathological Investigations on Weaning and Infant Mortality in the Early Middle Ages. Anthropologischer Anzeiger 58: 345-55.

Di Vito, Robert A. 1993. Studies in Third Millennium Personal Names: The Designation and Conception of the Personal God. Studia Pohl: Series Maior 16. Rome: Editrice Pontificio Istituto Biblico.

Domar, Evsey D. 1970. The Causes of Slavery or Serfdom: A Hypothesis. The Journal of Economic History: 30: 18-32. 
Dupras, Tosha, Henry P. Schwarcz, and Scott I. Fairgrieve. 2001. Infant Feeding and Weaning Practices in Roman Egypt. American Journal of Physical Anthropology 115: 204-12.

Eltis, David and Stanley L. Engerman. 1992. Was the Slave Trade Dominated by Men? Journal of Interdisciplinary History 23: 237-57.

Eltis, David and Stanley L. Engerman. 1993. Fluctuations in Sex and Age Ratios in the Transatlantic Slave Trade, 1663-1864. The Economic History Review 46: 308-23.

Eltis, David and Stanley L. Engerman. 2011. Dependence, Servility, and Coerced Labor in Time and Space. In The Cambridge History of World Slavery 3, eds. Eltis, David and Stanley L. Engerman. Cambridge: Cambridge University Press: 1-21.

Engelen, Theo and Arthur P. Wolf. 2005. Introduction: Marriage and the Family in Eurasia, Perspectives on the Hajnal Hypothesis. In Marriage and the Family in Eurasia, eds. Theo Engelen and Arthur P. Wolf. Amsterdam: Aksant Academic Publishers: 15-34.

Evans, D. G. 1963. The Incidence of Labour-Service in the Old Babylonian Period.JAOS 83: 20-26.

Fales, Frederick Mario. 2009-10. On Assyrian "Lower-stratum" Families. State Archives of Assyria Bulletin 18: 163-86.

Fales, Frederick Mario and J.N. Postgate. 1995. Imperial Administrative Records Part II. SAA 11. Helsinki: Helsinki University Press.

Faust, Avraham. 2007. Settlement Dynamics and Demographic Fluctuations in Judah from the Late Iron Age to the Hellenistic Period and the Archaeology of PersianPeriod Yehud. In A Time of Change: Judah and Its Neighbors in the Persian and Early Hellenistic Periods, ed. Yigal Levin. London: Continuum: 23-51.

Fensham, F. Charles. 1962. Widow, Orphan, and the Poor in Ancient Near Eastern Legal and Wisdom Literature. JNES 21:129-39.

Fildes, Valerie A. 1986. Breasts, Bottles, and Babies. Edinburgh: Edinburgh University Press.

Fogel, Robert William and Stanley L. Engermann. 1974. Time on the Cross:The Economics of American Negro Slavery. New York: W.W. Norton and Company.

Ford, Clellan Stearns. 1945. A Comparative Study of Human Reproduction. Yale University Publications in Anthropology 32. New Haven: Yale University Press.

Foster, Benjamin R. 2005. Before the Muses: An Anthology of Akkadian Literature. Bethesda, Maryland: cDL Press.

Foster, Benjamin R. 2010. On Personnel in Sargonic Girsu. In Veysel Donbaz'a Sunulan Yazular DUB.SAR É.DUB.BA.A, Studies Presented in Honour of Veysel Donbaz, ed. Şevket Dönmez. Istanbul: Ege: 143-51.

Foster, Catherine P. and Bradley J. Parker. 2012. Introduction: Household Archaeology in the Near East and Beyond. In New Perspectives on Household Archaeology, eds. Bradley J. Parker and Catherine P. Foster. Winona Lake, Indiana: Eisenbrauns. 
Frayne, Douglas R. 2008. Presargonic Period (2700-2350 B.C.). RIME 1. Toronto: University of Toronto Press.

Friedlander, D., Okun, B. S. and Segal, S. 1999. The Demographic Transition Then and Now: Processes, Perspectives and Analyses'. Journal of Family History 24: 493-533.

Fuller, B.T. et al. 2006. Isotopic Evidence for Breastfeeding and Possible Adult Dietary Differences from Late/Sub-Roman Britain. American Journal of Physical Anthropology 129: 45-54.

Galil, Gershon. 2007. The Lower Stratum Families in the Neo-Assyrian Period. CHANE 27. Leiden: Brill.

Gallant, Thomas W. 1991. Risk and Survival in Ancient Greece. Stanford: Stanford University Press.

Gehlken, Erlend. 2005. Childhood and Youth, Work and Old Age in Babylonia-a Statistical Analysis. In Approaching the Babylonian Economy, eds. Heather D. Baker and Michael Jursa. Münster: Ugarit-Verlag: 89-120.

Gelb. I.J. 1965. The Ancient Mesopotamian Ration System. JNES 24: 230-43.

Gelb. I.J. 1972. From Freedom to Slavery. In Gesellschaftsklassen im Alten Zweistromland und in den angrenzenden Gebieten XVIII. Rencontre assyriologique internationale, München, 29. Juni bis 3.Juli 1970, ed. D.O. Edzard. Munich: Bayerische Akademie der Wissenschaften: 81-92.

Gelb. I.J. 1979. Household and Family in Early Mesopotamia. In State and Temple Economy in the Ancient Near East, ed. Edward Lipinski. Leuven: Department of Oriëntalistiek: 1-99.

Gelb. I.J. 1980. Comparative Method in the Study of the Society and Economy of the Ancient Near East. Rocznik Orientalistyczny 41: 29-36.

Gibson, McGuire. 1973. Population Shift and the Rise of Mesopotamian Civilization. In The Explanation of Culture Change: Models in Prehistory, ed. Colin Renfrew. London: Duckworth: 447-63.

Goody, Jack. 1976. Introduction. In Family and Inheritance: Rural Society in Western Europe, 1200-180o eds. Jack Goody, Joan Thirsk, and E.P. Thompson. Cambridge: Cambridge University Press: 1-9.

Granqvist, Hilma. 1947. Birth and Childhood among the Arabs. Helsinki: Söderström and Company Förlagsaktiebolag.

Grayson, A. Kirk and Jamie Novotny. 2014. The Royal Inscriptions of Sennacherib, King of Assyria (704-681 BC), Part 2. Winona Lake, Indiana: Eisenbrauns.

Gruber, Mayer I. 1989. Breast-feeding Practices in Biblical Israel and in Old Babylonian Mesopotamia. JANES 19: 61-83.

Habicht, J.P. et al. 1985. The Contraceptive Role of Breastfeeding. Population Studies 39: 213-32.

Hajnal, J. 1965. European Marriage Patterns in Perspective. In Population in History, eds. D.V. Glass and D.E.C. Eversley. London: Edward Arnold: 101-43. 
Hallam, H.E. 1958. Some Thirteenth-Century Censuses. Economic History Review $N S: 340-61$.

Hanley, Susan B. 1974. Fertility, Mortality, and Life Expectancy in Pre-Modern Japan. Population Studies 28: 127-42.

Harris, W.V. 1999. Demography, Geography and the Sources of Roman Slaves. The Journal of Roman Studies 89: 62-75.

Heeßel, Nils P. 2008. Reading and Interpreting Medical Cuneiform Texts-Methods and Problems. Le Journal des médecines cunéiformes 3/1: 2-9.

Hendrickx, François. 2005. West of the Hajnal Line: North-western Europe. In Marriage and the Family in Eurasia, eds. Theo Engelen and Arthur P. Wolf. Amsterdam: Aksant Academic Publishers: 73-103.

Herring, D. Ann, S.R. Saunders, and M.A. Katzenberg. 1998. Investigating the Weaning Process in Past Populations. American Journal of Physical Anthropology 105: 425-39.

Hin, Saskia. 2013. The Demography of Roman Italy: Population Dynamics in an Ancient Conquest Society. Cambridge: Cambridge University Press.

Hoch, Steven L. 1982. Serfs in Imperial Russia: Demographic insights. The Journal of Interdisciplinary History 13: 221-246.

Hogan, Dennis P. and David I. Kertzer. 1986. The Social Bases of Declining Infant Mortality: Lessons from a Nineteenth-Century Italian Town. European Journal of Population 2: 361-85.

Huebner, Sabine R. 2013. The Family in Roman Egypt: A Comparative Approach to Intergenerational Solidarity and Conflict. Cambridge: Cambridge University Press.

INDEPTH Network. 2004. INDEPTH Model Life Tables for Sub-Saharan Africa.

Burlington, Vermont: Ashgate Publishing.

IPEC and SIMPOC. 2002. Every Child Counts: New Global Estimates on Child Labour.

Geneva: International Labour Office.

Jacobsen, Thorkild. 1987. The Harps that Once ... Sumerian Poetry in Translation. New Haven: Yale University Press.

Jursa, Michael. 2010. Aspects of the Economic History of Babylonia in the First Millennium B.C. Münster: Ugarit-Verlag.

Jursa, Michael. 2014. Factor Markets in Babylonia from the Late Seventh to the Third Century BCE. JE SHO 57: 173-202.

Jursa, Michael. 2015. Labor in Babylonia in the First Millennium BC. In Labor in the Ancient World, eds. Piotr Steinkeller and Michael Hudson. Dresden: IS LET: 345-96.

Kertzer, David I. 1991. Household History and Sociological Theory. Annual Review of Sociology 17: 155-79.

Kilmer, Anne Draffkorn. 1972. The Mesopotamian Concept of Overpopulation and its Solution as Reflected in the Mythology. Orientalia, Nova Series 41: 160-77.

Kleber, Kristin. 2011. Neither Slave nor Truly Free. In Slaves and Households in the Near East, ed. Laura Culbertson. Chicago: The Oriental Institute of the University of Chicago: 101-11. 
Kleber, Kristin. 2012. Famine in Babylonia: A Microhistorical Approach to an Agricultural Crisis in 528-526 вС. ZA 102: 219-44.

Koschaker, P. 1950. Eheschliessung und Kauf nach alten Rechten, mit besonderer Berücksichtigung der älteren Keilschriftrechte. Archív Orientálni 18: 210-96.

Lambert, W.G. 2013. Babylonian Creation Myths. Winona Lake, Indiana: Eisenbrauns.

Laslett, Peter. 1974. Introduction: The History of the Family. In Household and Family in Past Time, ed. Peter Laslett with assistance of Richard Wall. Cambridge: Cambridge University Press: 1-89.

Layard, Austin Henry. 1853. Monuments of Nineveh 2. London: John Murray.

Levy, Marion J. 1965. Aspects of the Analysis of Family Structure. In Aspects of the Analysis of Family Structure, eds. Ansley J. Coale et al. Princeton: Princeton University Press: $1-63$.

Liverani, Mario. 1987. The Collapse of the Near Eastern Regional System at the End of the Bronze Age: The Case of Syria. In Centre and Periphery in the Ancient World, eds. Michael Rowlands, Mogens Larsen, and Kristian Kristiansen. Cambridge: Cambridge University Press.

Lundh, Christer. 2014. Similarity in Difference: Marriage in Europe and Asia, 1700-19oo. Cambridge, Massachusetts: MIT Press.

Marciniak, Stephanie, et al. 2016. Plasmodium falciparum Malaria in 1st-2nd Century CE Southern Italy. Current Biology 26: R1205-1255.

McClellan, Thomas L. 1997. Houses and Households in North Syria during the Late Bronze Age. In Les maisons dans la Syrie antique du III ${ }^{e}$ millénaire aux débuts de l'Islam. Beirut: IFAPO: 29-49.

McMahon, Augusta. 2015. Waste Management in Early Urban Southern Mesopotamia. In Sanitation, Latrines, and Intestinal Parasites in Past Populations, ed. Piers D. Mitchell. Farnham: Ashgate Publishing: 19-39.

Menard, Russell R. 1975. The Maryland Slave Population, 1658-1730: A Demographic Profile of Blacks in Four Counties. The William and Mary Quarterly, Third Series 32: 29-54.

Milgrom, Jacob. 2000. Leviticus 23-27. New York: Doubleday.

Mitchell, Piers D. 2015. Human Parasites in the Roman World: Health Consequences of conquering and Empire. Parasitology (online): 1-11.

Moortgat, Anton. 1967. Die Kunst des alten Mesopotamien. Köln: Verlag M. DuMont Schauberg.

Netting, Robert McC. 1982. Some Home Truths on Household Size and Wealth. American Behavioral Scientist.

Nieboer, H.J. 19oo. Slavery as an Industrial System. The Hague: M. Nijhoff.

Oded, Bustenay. 1979. Mass Deportations and Deportees in the Neo-Assyrian Empire. Wiesbaden: Dr. Ludwig Reichert Verlag.

Oppenheim, A. Leo. 1955. Siege Documents from Nippur. Iraq 17: 69-89. 
Ortner, D.J. 2001. Disease Ecology. In Handbook of Archaeological Sciences, eds. D.R. Brothwell and A.M. Pollard. Chichester: John Wiley and Sons: 225-35.

Parkin, Tim. 2013. The Demography of Infancy and Early Childhood in the Ancient World. In The Oxford Handbook of Childhood and Education in the Classical World, eds. Judith Evans Grubbs and Tim Parkin. Oxford: Oxford University Press: 40-61.

Parpola, Simo. 1983, Letters from Assyrian Scholars to the Kings Esarhaddon and Assurbanipal Part II: Commentaries and Appendices. AOAT 5/2. Kevelaer: Butzon and Bercker.

Patterson, Orlando. 1992. Slavery and Social Death. Cambridge, Massachusetts: Harvard University Press.

Paulette, Tate. 2013. Consumption and Storage in the Bronze Age. In Models of Mesopotamian Landscapes: How Small-Scale Processes Contributed to the Growth of Early Civilizations, eds. T.J. Wilkinson, M. Gibson, and M. Widell. BAR International Series 2013. Oxford: Archaeopress: 102-111.

Petschow, Herbert P.H. 1983. Die Sklavenkaufverträge des šandabakku Enlil-kidinn̄̄ von Nippur. Orientalia 52: 143-55.

Plakans, Andrejs. 1984. Serf emancipation and the changing structure of rural domestic groups in the Russian Baltic provinces: Linden Estate, 1797-1858. In Households, Comparative and Historical Studies of the Domestic Group, eds. Robert McC. Netting, Richard R. Wilk, and Eric J. Arnould. Berkeley: University of California Press: 245-275.

Postgate, Nicholas. 1994a. Early Mesopotamia: Society and Economy at the Dawn of History. New York: Routledge.

Postgate, Nicholas. 1994b. How Many Sumerians per Hectare?-Probing the Anatomy of an Early City. Cambridge Archaeological Journal 4: 47-65.

Postgate, Nicholas. 2007. Ilku and Land Tenure in the Middle Assyrian KingdomA Second Attempt. In The Land of Assur \& the Yoke of Assur: Studies on Assyria 19712005. Oxford: Oxbow Books: 112-21.

Postgate, Nicholas. 2013. Bronze Age Bureaucracy: Writing and the Practice of Government in Assyria. Cambridge: Cambridge University Press.

Pudsey, April. 2013. Children in Roman Egypt. In The Oxford Handbook of Childhood and Education in the Classical World, eds. Judith Evans Grubbs and Tim Parkin. Oxford: Oxford University Press: 484-509.

Reade, Julian. 1998. Assyrian Sculpture. London: British Museum Press.

Reid, John Nicholas. 2015. Runaways and Fugitive-Catchers during the Third Dynasty of Ur. JE SHO 58: 576-605.

Richardson, Seth. 2015. Building Larsa: Labor-Value, Scale and Scope-of-Economy in Ancient Mesopotamia. In Labor in the Ancient World, ed. Piotr Steinkeller and Michael Hudson. Dresden: ISLET: 237-328.

Roberts, Charlotte and Keith Manchester. 2005. The Archaeology of Disease. Ithaca: Cornell University Press. 
Robson, Eleanor. 2008. Mesopotamian Medicine and Religion: Current Debates, New Perspectives. Religion Compass 2/4: 455-83.

Roth, Martha T. 1987. Age at Marriage and the Household: A Study of Neo-Babylonian and Neo-Assyrian Forms. Comparative Studies in Society and History 29: 715-47.

Roth, Martha T. 1997. Writings from the Ancient World 6: Law Collections from Mesopotamia and Asia Minor. Atlanta: Scholars Press.

Rutz, Matthew. 2011. Threads for Esagil-kīn-apli: The Medical Diagnostic-Prognostic Series in Middle Babylonian Nippur. ZA 101: 294-308.

Saito, Osamu. 2005. The Third Pattern of Marriage and Remarriage: Japan in Eurasian Comparative Perspectives. In Marriage and the Family in Eurasia, eds. Theo Engelen and Arthur P. Wolf. Amsterdam: Aksant Academic Publishers: 165-194.

Salah, Saqer. 2014. Die mittelassyrischen Personen- und Rationenlisten aus Tall Šêh Hamad/Dür-Katlimmu. BATsH 18. Wiesbaden: Harrassowitz.

Sallaberger, Walther and Alexander Pruß. 2015. Home and Work in Early Bronze Age Mesopotamia: "Ration Lists" and "Private Houses" at Tell Beydar/Nabada. In Labor in the Ancient World, eds. Piotr Steinkeller and Michael Hudson. Dresden: ISLET: 69-136.

Sbonias, Kostas. 1999. Investigating the Interface between Regional Survey, Historical Demography, and Paleodemography. In Reconstructing Past Population Trends in Mediterranean Europe (зо0о BC-AD 180o), eds. John Bintliff and Kostas Sbonias. Oxford: Oxbow Books: 219-34.

Scheidel, Walter. 2005. Real Slave Prices and the Relative Cost of Slave Labor in the Greco-Roman World', in: Ancient Society 35 (2005), 1-17.

Scheidel, Walter. 2007. Demography. In The Cambridge Economic History of the GrecoRoman World, eds. Walter Scheidel, Ian Morris, and Richard Saller. Cambridge: Cambridge University Press: 38-86.

Schloen, J. David. 2001. The House of the Father as Fact and Symbol. Winona Lake, Indiana: Eisenbrauns.

Scurlock, JoAnn and Burton R. Andersen. 2005. Diagnoses in Assyrian and Babylonian Medicine. Urbana: University of Illinois Press.

Sen, Amartya. 1992. Missing Women: Social Inequality Outweighs Women's Survival Advantage in Asia and North Africa. British Medical Journal 304: n6827 587(1-2).

Sen, Amartya. 2003. Missing Women Revisited: Reduction in Female Mortality Has Been Counterbalanced by Sex Selective Abortions. BMJ 327: 1297-8.

Seri, Andrea. 2013. The House of the Prisoners: Slavery and State in Uruk during the Revolt against Samsu-iluna. Berlin: De Gruyter.

Seri, Andrea. 2014. Borrowings to Create Anew: Intertextuality in the Babylonian Poem of "Creation" (Enūma eliš). JAos 134: 89-106.

Short, R.V. 1984. Breast Feeding. Scientific American 250: 35-39. 
Skinner, G. William. 1997. Family Systems and Demographic Processes. In Anthropological Demography: Toward a New Synthesis. Chicago: University of Chicago Press: 53-95.

Smith, Earl and Angela Hattery. 2007. If We Build It They Will Come: Human Rights Violations and the Prison Industrial Complex. Societies Without Borders 2: 273-88.

Steinkeller, Piotr. 1993. Early Political Developments in Mesopotamia and the Origins of the Sargonic Empire. In Akkad: The First World Empire. ed. Mario Liverani. Padova: Sargon: 107-29.

Steinkeller, Piotr. 2002. Money-Lending Practices in Ur III Babylonia: The Issue of Economic Motivation. In Debt and Renewal in the Ancient Near East, eds. H. Hudson and M. van de Mieroop. Bethesda, Maryland: CDL Press: 109-37.

Steinkeller, Piotr. 2004. Toward a Definition of Private Economic Activity in Third Millennium Babylonia. In Commerce and Monetary System in the Ancient World: Means of Transmission and Cultural Interaction, eds. Robert Rollinger and Christoph Ulf. Stuttgart: Franz Steiner Verlag: 91-111.

Steinkeller, Piotr. 2015a. Labor in the Early States: An Earl Mesopotamian Perspective. In Labor in the Ancient World, ed. Piotr Steinkeller and Michael Hudson. Dresden: ISLET: 1-35.

Steinkeller, Piotr. 2015b. The Employment of Labor on National Building Projects in the Ur III Period. In Labor in the Ancient World, ed. Piotr Steinkeller and Michael Hudson. Dresden: ISLET: 137-236.

Steinkeller, Piotr. and Michael Hudson, eds. 2015. Labor in the Ancient World. Dresden: ISLET: 137-236.

Stol, M. 1995a. Women in Mesopotamia. JESHO 38: 123-44.

Stol, M. 1995b. Old Babylonian Corvée (tupšikkum). In Studio Historiae Ardens: Ancient Near Eastern Studies Presented to Philo H.J. Houwink ten Cate on the Occasion of his 65 th Birthday, eds. Theo .J. van den Hout and Johan de Roos. Leiden: Nederlands Instituut voor het Nabije Oosten: 293-309.

Stol, M. 2000. Birth in Babylonia and the Bible. Cuneiform Monographs 14. Groningen: Styx Publications.

Stone, E. 1981. Texts, Architecture and Ethnographic Analogy: Patterns of Residence in Old Babylonian Nippur. Iraq 43: 19-33.

Struve, V.V. 1969a. The Problem of the Genesis, Development and Disintegration of the Slave Societies in the Ancient Orient. In Ancient Mesopotamia: Socio-Economic History. Moscow: Nauka Publishing House.

Struve, V.V. 1969b. Some New Data on the Organization of Labour and on Social Structure in Sumer during the Reign of the IIIrd Dynasty of Ur. In Ancient Mesopotamia: Socio-Economic History. Moscow: Nauka Publishing House.

Studevent-Hickman, Benjamin. 2006. Organization of Manual Labor in Ur III Umma. Ph.D. diss. Harvard University. 
Tenney, Jonathan S. 2011a. Life at the Bottom of Babylonian Society: Servile Laborers at Nippur in the 14th and 13th Centuries B.C. Culture and History of the Ancient Near East 51. Leiden: Brill.

Tenney, Jonathan S. 2011b. Household Structure and Population Dynamics in the Middle Babylonian Provincial "Slave" Population. In Slavery and Household in the Ancient Near East, ed. Laura Culbertson. OIS 7. Chicago: Oriental Institute Press.

Tenney, Jonathan S. 2016. The Elevation of Marduk Revisited: Festivals and Sacrifices at Nippur in the High Kassite Period.Jcs 68 (in press).

Tenney, Jonathan S. In press. A Servile Population in Kassite Nippur: A Brief Overview. In Karduniaš: Babylonien in der Kassitenzeit, eds. Michael Roaf and A. Bartelmus. Munich: De Gruyter.

Ur, Jason. 2014. Households and the Emergence of Cities in Ancient Mesopotamia. Cambridge Archaeological Journal 24: 249-68.

Ur, Jason et al. 2013. Ancient Cities and Landscapes in the Kurdistan region of Iraq: The Erbil Plain Archaeological Survey 2012 Season. Iraq 75: 89-117.

Van Bavel, J. 2004. Deliberate Birth Spacing before the Fertility Transition in Europe:

Evidence from Nineteenth-Century Belgium', Population Studies 58: 95-107. van de Mieroop, Marc. 1993. The Reign of Rim-Sin. $R A$ 87:47-69.

van de Mieroop, Marc. 2004. Economic Theories and the Ancient Near East. In Commerce and Monetary Systems in the Ancient World: Means of Transmission and Cultural Interaction, eds. Robert Rollinger and Christoph Rulf. Stuttgart: Franz Steiner Verlag: 54-64.

van de Mieroop, Marc. 2007. A History of the Ancient Near East. Malden, Massachusetts: Blackwell Publishing. van Soldt, Wilfred. 2015. Middle Babylonian Texts in the Cornell University Collections I. The Later Kings. Bethesda, Maryland: CDL Press.

Viazzo, Per Paolo. 2005. South of the Hajnal Line. Italy and Southern Europe. In Marriage and the Family in Eurasia, eds. Theo Engelen and Arthur P. Wolf. Amsterdam: Aksant Academic Publishers: 129-63.

Vidal, Jordi. 2014. On the Demography of Ugaritian Villages: A Research Note. JESHO 57: 44-54.

von Dassow, Eva. 2008. State and Society in the Late Bronze Age: Alalah under the Mitanni Empire. scCNH 17. Bethesda, Maryland: CDL Press.

von Dassow, Eva. 2011. Freedom in Ancient Near Easter Societies. In The Oxford Handbook of Cuneiform Culture, ed. Karen Radner and Eleanor Robson. Oxford: Oxford University Press: 205-24.

Waetzoldt, Harmut. 1987. Compensation of Craft Workers and Officials in the Ur III Period. In Labor in the Ancient Near East, ed. Marvin A. Powell. American Oriental Series 68. New Haven: American Oriental Society: 117-41. 
Westbrook, Raymond. 2003. Introduction: The Character of Ancient Near Eastern Law. In A History of Ancient Near Eastern Law 1. ed. Raymond Westbrook. Leiden: Brill: 1-90.

Wickes, Ian G. 1953. A History of Infant Feeding Part 1. Archives of Disease in Childhood 28: 151-58.

Widell, Magnus. 2005. Some Reflections on Babylonian Exchange. JESHO 48: 388-400.

Widell, Magnus et al. 2013. Household and Village in Early Mesopotamia. In Models of Mesopotamian Landscapes, eds. T.J. Wilkinson, McGuire Gibson, Magnus Widell. Oxford: Archaeopress: 112-29.

Wiggermann, F.A.M. 2000. Agriculture in the Northern Balikh Valley. The Case of Middle Assyrian Tell Sabi Abyad. In Rainfall and Agriculture in Northern Mesopotamia, ed. R.M. Jas. Leiden: Nederlands Instituut voor het Nabije Oosten: 171-215.

Wilkinson, Tony. 1999. Demographic Trends from Archaeological Survey: Case Studies from the Levant and Near East. In Reconstructing Past Population Trends in Mediterranean Europe (300о BC-AD 180o), eds. John Bintliff and Kostas Sbonias. Oxford: Oxbow Books: 45-64.

Wilkinson, Tony, Jason A. Ur, and Carrie Hritz. 2013. Settlement Archaeology of Mesopotamia. In Models of Mesopotamian Landscapes: How Small-Scale Processes Contributed to the Growth of Early Civilizations, eds. T.J. Wilkinson, M. Gibson, and M. Widell. BAR International Series 2013. Oxford: Archaeopress: 34-55.

Wilkinson, Tony et al. 2005. Landscape and Settlement in the Neo-Assyrian Empire. BASOR 340: 23-56.

Wilkinson, Tony et al. 2012. Late Chalcolithic and Early Bronze Age Landscapes of Settlement and Mobility in the Middle Euphrates: A Reassessment. Levant 44: 139-85.

Wilkinson, Tony et al. 2014. Contextualizing Early Urbanization: Settlement Cores, Early States and Agro-pastoral Strategies in the Fertile Crescent During the Fourth and Third Millennia NC. Journal of World Prehistory 27: 43-109.

Woods, Robert. 2007. Ancient and Early Modern Mortality: Experience and Understanding. The Economic History Review, New Series 6o: 373-399.

Wright, Lori E. and Henry P. Schwarcz. 1998. Stable Carbon and Oxygen Isotopes in Human Tooth Enamel: Identifying Breastfeeding and Weaning in Prehistory. American Journal of Physical Anthropology 106: 1-18.

Wunsch, Cornelia. 2003/2004. Findelkinder und Adoption nach neubabylonischen Quellen. AfO 50: 174-244.

Yoffee, Norman. 2004. Myths of the Archaic State. Cambridge: Cambridge University Press.

Zimmerman, M.R. 2001. The Study of Preserved Human Tissue. In Handbook of Archaeological Sciences, eds. D.R. Brothwell and A.M. Pollard. Chichester: John Wiley and Sons: 249-57. 